Article

\title{
In Vitro Probiotic Potential and Safety Evaluation (Hemolytic, Cytotoxic Activity) of Bifidobacterium Strains Isolated from Raw Camel Milk
}

\author{
Iqra Yasmin ${ }^{1,2}, * \mathbb{C}$, Muhammad Saeed ${ }^{3}$, Wahab Ali Khan ${ }^{3} \mathbb{C}$, Adnan Khaliq ${ }^{4}$, \\ Muhammad Farhan Jahangir Chughtai ${ }^{4}{ }^{\circledR}$, Rabia Iqbal ${ }^{1}$, Saima Tehseen ${ }^{1}$, Saima Naz ${ }^{5}$, \\ Atif Liaqat ${ }^{4}$, Tariq Mehmood ${ }^{4}$, Samreen Ahsan ${ }^{4}$ and Saira Tanweer ${ }^{6}$ \\ 1 Department of Food Science and Technology, Government College Women University, Faisalabad 38040, \\ Pakistan; rabi1300@hotmail.com (R.I.); dr.saimatehseen@gcwuf.edu.pk (S.T.) \\ 2 Barani Agricultural Research Institute, Chakwal 48800, Pakistan \\ 3 National Institute of Food Science and Technology, Faculty of Food, Nutrition and Home Sciences, University \\ of Agriculture, Faisalabad 38040, Pakistan; drmsaeed@uaf.edu.pk (M.S.); w.a.khan31@hotmail.com (W.A.K.) \\ 4 Department of Food Science and Technology, Khwaja Fareed University of Engineering and Information \\ Technology, Rahem Yar Khan 64200, Pakistan; adnan1103.ft@gmail.com (A.K.); \\ m.farhan.chughtai@hotmail.com (M.F.J.C.); atifliaqat09@gmail.com (A.L.); \\ tariq.mehmood@kfueit.edu.pk (T.M.); samreenahsan.ft@gmail.com (S.A.) \\ 5 Department of Clinical Nutrition, Nur International University, Lahore 54000, Pakistan; \\ saimanaz2109@gmail.com \\ 6 University College of Agriculture and Environmental Sciences, Islamia University, Bahawalpur 63100, \\ Pakistan; sairatanweer1116@gmail.com \\ * Correspondence: iqrayasmin8@gmail.com
}

Received: 27 December 2019; Accepted: 16 February 2020; Published: 2 March 2020

\begin{abstract}
The present study was designed to isolate Bifidobacterium strains from raw camel milk and to investigate their probiotic characteristics. Among 35 isolates, 8 were identified as Gram-positive, catalase negative, non-spore forming, non-motile and V or Y shaped rods. B-2, B-5, B-11, B-19 and B-28 exhibited good survival at low $\mathrm{pH}$ and high bile salt concentration. Most of the isolates were resistant to nalidixic acid, fusidic acid, polymyxin B, neomycin, streptomycin, gentamicin, rifampicin and kanamycin. Furthermore, the production of exopolysaccharides (EPS), adhesion characteristics, antioxidant properties, antagonistic activities, nitrite reduction and cholesterol assimilation were also studied. Isolate B-11 was chosen because it exhibited most of the probiotic properties among all the tested isolates. It is identified as the member of Bifidobacterium longum group through $16 \mathrm{~S}$ rRNA gene sequencing and named as B. longum B-11. B. longum B-11 was further selected for in vivo attachment to rat intestine and scanning electron micrographs revealed that attachment of a large number of rods shaped bacterial cell. Our findings suggest that B. longum B-11 processes excellent attributes to be used as potential probiotic in the development of functional probiotic food.
\end{abstract}

Keywords: probiotic potential; antimicrobial activity; camel milk: B-11; pathogens

\section{Introduction}

Probiotics are the live microorganisms that confer certain health benefits to the host beyond basic nutrition (FAO/WHO 2006). They are proposed to provide certain health benefits i.e., balance gut microflora, alleviate gastrointestinal infections, inhibit the growth of pathogenic bacteria, strengthening the barrier function of the gut, improve immunity, assimilation of serum cholesterol, prevention from irritable bowel syndrome, reduce hypertension, prevent diarrhea and etc. [1]. Different genera of 
Lactococcus, Lactobacillus, Streptococcus, Bifidobacterium and various yeast strains have been well-studied probiotics. The main attribute in the identification and application of probiotics in the food matrix is they should be Generally Recognized As Safe (GRAS) for human consumption and provide probiotics microorganisms in sufficient amount at the time of consumption [2]. Selection of probiotics strain is also important for application in the food industry, their ability to survive and to keep their functional properties intact during processing and storage under harsh condition i.e., spray drying and freezing, along their survival during gastric transit [3].

Bifidobacteria are catalase-negative, Gram-positive, non-motile, non-spore forming, anaerobes belonging to phylum Actinobacteria. Bifidobacteria are saccharolytic organisms that hydrolyzed or metabolized carbohydrates. Bifidobacteria appear in V or Y shape, short rods, uniform, single or branched, bifurcated or clubbed [4]. The isolation of bifidobacteria as a potential probiotic culture, the antimicrobial agent is promising in a wide range of biotechnological and biomedical applications. These probiotics potentially used as microbial culture in food systems due to its safety aspects and various functional attributes [5].

Bifidobacteria exhibited tremendous biotechnological and functional attributes including the ability to survive in harsh gastrointestinal conditions that seem to vary among different strains of Bifidobacterium due to phenotypic and genotypic variations within the species. FAO and WHO have developed basic criteria for the screening and selection of probiotics. A probiotic strain must survive and colonized in the host's gastrointestinal tract. Probiotics ought to possess cell surface properties i.e., auto-aggregation, cell surface hydrophobicity, should tolerate low pH of stomach and bile salt [6-9]. Additionally, probiotics must have functional properties i.e., cholesterol assimilation, antagonistic and antioxidant activities to exert positive health benefits to the host [10]. Besides the functional attributes, the safety evaluation of probiotic such as resistance to antibiotics, blood hemolytic activity, antimutagenic activity, cytotoxicity, intestinal inflammatory cytokines, and the histopathological test must be performed before its contact with an animal or human.

Camel milk is gaining consumer's interest due to its various nutritional and therapeutic attributes. In hot, arid and semi-arid areas of Asia and Africa, camel milk is used as raw or in fermented form. In these regions, camel milk is considered a major dairy source for human nutrition. In the Middle East and Africa, mostly fermented camel milk products are being consumed. Studied revealed that camel milk is a rich source of beneficial microflora especially Lactic Acid Bacteria (LAB) and Bifidobacteria. Saudi Arabia, Somalia, and the United Arab Emirates (UAE) are the top camel milk producing countries all around the world. LAB is successfully isolated from camel milk and fermented camel milk products [11-20]. To the best of my knowledge, to date, no work has been published regarding the isolation of bifidobacteria from camel milk.

In previous years, the use of additive with antimicrobial properties gaining attention to introduce new and natural protective agents that don't induce antimicrobial-resistance genes. This bioprotective agent can be effectively used as an alternative of antibiotics for food preservation, food safety and biomedical application. Among natural preservatives, probiotics are one of the live alternatives due to the synthesis of organic acid and bacteriocins [21]. Recent studies on the antimicrobial activities of probiotics are prime importance in the control of pathogenic and food spoilage microorganisms. The effectiveness of bifidobacteria to control pathogenic bacteria has been well studied. Probiotics also have been studied for their effectiveness on the reduction of blood serum cholesterol. Studies revealed that consumption of probiotic dairy products significantly reduces total serum cholesterol and low-density lipoprotein (bad cholesterol) [22]. The probiotic potential and preservative effect of microorganisms depend upon isolation sources and species. It is a complex task to select the origin of probiotics for isolation but most of the probiotics are isolated from human origin and fermented products. Recently, more attention has been paid to isolate probiotic from indigenous sources to introduce new resources to improve the host's health. The gut microbiome composition differs from person to person due to diversity in geographic expanse, foods, habitat and lifestyle [23]. Thus, it is 
interesting to design cost-effective probiotic starter culture which has equal opportunity to be used as a probiotic and a food starter culture.

The aim of the current study was to isolate, characterized bifidobacteria from raw camel milk and to provide more inclusive report for their probiotic potential. The presumptive isolates were assessed for tolerance to gastric juice and bile salt. Additionally, probiotic potential and safety evaluation was confirmed through antioxidant, antibacterial activity, exopolysaccharide production, cholesterol assimilation, antibiotics susceptibility, hemolytic activity and cytotoxicity. On the basis of preliminary analysis, one of the best strains was identified through 16 rDNA sequencing.

\section{Materials and Methods}

\subsection{Chemicals}

All media, chemicals, reagent and kits used in this study were of analytical grade and purchased from St. Louis, MO, USA., Sigma-Aldrich Chemicals Ltd., Merck and Co. Inc. and White House Station, NJ, USA.

\subsection{Sample Collection and Isolation}

Forty-five raw camel milk samples were collected from local lactating healthy camels (Camelus dromedaries) from different regions of Punjab, Pakistan. The samples were collected into a sterilized container. Due to long-distance, samples were placed in iceboxes until delivered to the Food Microbiology and Biotechnology Laboratory, NIFSAT, UAF and immediately analyzed upon arrival. Samples were homogenized $(10 \% \mathrm{w} / \mathrm{v})$ in sterile phosphate buffer using stomacher. After preparation of dilutions in sterile saline $(0.85 \% w / v \mathrm{NaCl})$, the samples were plated on de Man Rogosa Sharpe (MRS) agar (Difco, Sparks, MD, USA) supplemented with L-cysteine 0.05\% (w/v) (Sigma Aldrich, St. Louis, MO, USA). Plates were incubated anaerobically in an anaerobic chamber (Bactron Shel Lab II-1, Sheldon Manufacturing Inc., Cornelius, OR, USA) at $37^{\circ} \mathrm{C}$ for $48 \mathrm{~h}$. After incubation, morphologically dissimilar colonies were selected and re-streaked on an agar plate to get pure isolates.

\subsection{Preliminary Identification and Screening of Bifidobacterium}

All isolates (35) were analyzed on the basis of morphology, Gram staining, catalase test, motility test and endospore test. After preliminary screening, 8 isolates were identified as a member of genus Bifidobacterium on the basis of Gram-positive, catalase-negative, non-spore forming, non-motile and $\mathrm{V}$ or $\mathrm{Y}$ shaped rods. These isolates were further analyzed for growth characteristics i.e., growth at various temperatures $\left(10^{\circ} \mathrm{C}, 37^{\circ} \mathrm{C}\right.$ and $\left.45^{\circ} \mathrm{C}\right)$, growth at different $\mathrm{NaCl}$ concentrations $(3 \%, 5 \%$ and $7 \%$ ) and growth at various $\mathrm{pH}$ (4.4 to 9.6). These isolates were also analyzed for their ability to produce $\mathrm{CO}_{2}$ and ferment various sugar by using API $50 \mathrm{CH}$ kit. Microscopic examination was performed by using the EVOS FL Auto Cell Imaging System (Thermo Fisher Scientific, Waltham, MA, USA). The pure isolate was preserved in MRS broth in $30 \%$ glycerol at $-80{ }^{\circ} \mathrm{C}$ as a frozen stock. The culture was reactivated prior to use by sub-culturing at least 3 times in MRS broth.

\subsection{In Vitro Screening of Probiotic Potential of Isolates}

\subsubsection{Survival under Gastrointestinal Conditions and Phenol Tolerance}

Isolates were screened for their ability to withstand in harsh gastrointestinal conditions i.e., low gastric $\mathrm{pH}$, bile salt and $0.4 \%(\mathrm{w} / \mathrm{v})$ phenol. Isolates were cultivated in MRS broth to get the desired cell number $\left(10^{9} \operatorname{logs} \mathrm{CFU} / \mathrm{mL}\right)$ after $18 \mathrm{~h}$ of incubation at $37^{\circ} \mathrm{C}$. The simulated gastric juice (SGJ) containing pepsin $(3 \mathrm{~g} / \mathrm{L})$ was prepared in sterile saline $(0.85 \%, w / v \mathrm{NaCl})$ and adjusted the $\mathrm{pH} 2,3$ by using $1 \mathrm{M} \mathrm{HCl} .1 \mathrm{~mL}\left(10^{9} \operatorname{logs} \mathrm{CFU} / \mathrm{mL}\right)$ of overnight grown cell suspension was mixed with $9 \mathrm{~mL}$ of sterilized SGJ under aseptic conditions and incubated at $37^{\circ} \mathrm{C}$ for $2 \mathrm{~h}$. Similarly, tolerance to bile salt and phenol was evaluated by inoculating bacterial suspension $\left(1 \mathrm{~mL}\right.$ containing $\left.10^{9} \operatorname{logs} \mathrm{CFU} / \mathrm{mL}\right)$ in 
MRS broth tubes containing a various concentration of bile salt $(0.1 \%, 0.5 \%$ and $1 \% \mathrm{w} / \mathrm{v})$ and phenol $(0.4 \%, \mathrm{w} / \mathrm{v})[24]$. After incubation, the viable count was determined by plating and expressed as $\mathrm{CFU} / \mathrm{mL}[25]$.

\subsubsection{Production of Exopolysaccharides (EPS)}

The EPS production was determined as described by Liu, et al. [26]. 1\% (v/v) of each isolated bacterial culture $\left(10^{9} \mathrm{CFU} / \mathrm{mL}\right)$ was inoculated into MRS broth supplemented with $2 \%(\mathrm{w} / \mathrm{v})$ glucose and incubated $\left(37^{\circ} \mathrm{C}\right.$ for $24 \mathrm{~h}$ ). After completion of incubation, cell pellets were removed by centrifugation (4000× g, at $4{ }^{\circ} \mathrm{C}$ for $\left.10 \mathrm{~min}\right)$. Trichloroacetic acid $4 \%(\mathrm{w} / \mathrm{v})$ was added and mixture was vortex at $4{ }^{\circ} \mathrm{C}$ for $3 \mathrm{~h}$. Precipitated proteins were removed through centrifugation $(22,000 \times \mathrm{g}, 20 \mathrm{~min})$, supernatant was concentrated through evaporation. Four volumes of ethanol $(95 \%, \mathrm{v} / \mathrm{v})$ was added to precipitated EPS, the mixture was centrifuged $\left(22,000 \times \mathrm{g}\right.$, at $4{ }^{\circ} \mathrm{C}$ for $\left.20 \mathrm{~min}\right)$ and stored for $24 \mathrm{~h}$ at $4{ }^{\circ} \mathrm{C}$. EPS was dialyzed (6000 Da to $8000 \mathrm{Da}$ molecular weight) for $48 \mathrm{~h}$ at $4{ }^{\circ} \mathrm{C}$ and freeze-dried to make powder. The EPS amount was calculated by following the phenol sulfuric acid method [27].

\subsubsection{Auto-Aggregation Assay}

The auto-aggregation assay was accomplished by following the method as described by $\mathrm{Xu}$, et al. [28] with little modifications. Overnight culture of all the tested isolates were collected after centrifugation $\left(4000 \times \mathrm{g}\right.$, at $4^{\circ} \mathrm{C}$ for $\left.10 \mathrm{~min}\right)$. The cells were washed two times with phosphate buffer saline (PBS) and re-suspended in PBS to reach an absorbance of $(0.5 \pm 0.02)$ at $600 \mathrm{~nm}$ at $0 \mathrm{~h}\left(\mathrm{~A}_{0}\right)$. Then, $1 \mathrm{~mL}$ of each bacterial suspension was vortexed for $5 \mathrm{sec}$ and incubated $\left(37^{\circ} \mathrm{C}\right.$ for $2 \mathrm{~h}, 6 \mathrm{~h}, 12 \mathrm{~h}$ and $24 \mathrm{~h}$ ). Supernatant absorbance was measured at $600 \mathrm{~nm}$ after $2 \mathrm{~h}, 6 \mathrm{~h}, 12 \mathrm{~h}$ and $24 \mathrm{~h}$ of incubation $\left(\mathrm{A}_{2}\right)$ of incubation (Equation (1)).

$$
\text { Autoaggregation }(\%)=1-(\mathrm{A} 2 / \mathrm{A} 0) \times 100
$$

Whereas, $\mathrm{A}_{0}=$ Initial absorbance at $0 \mathrm{~h} ; \mathrm{A}_{2}=$ Final absorbance after $2 \mathrm{~h}, 6 \mathrm{~h}, 12 \mathrm{~h}$ and $24 \mathrm{~h}$ of incubation

\subsubsection{Cell Surface Hydrophobicity}

Cell surface hydrophobicity was evaluated via all the 8 isolated bacteria that have the ability to bind with hydrocarbons by following the method as described by Kotzamanidis, et al. [29] with slight modifications. Briefly, overnight grown cells were collected after centrifugation $\left(4000 \times \mathrm{g}\right.$, at $4{ }^{\circ} \mathrm{C}$ for $10 \mathrm{~min}$ ). The cells were washed two times with PBS having $\mathrm{pH} 7$ and resuspended in PBS to reach an absorbance of $(0.5 \pm 0.02)$ at $600 \mathrm{~nm}$ at $0 \mathrm{~h}\left(\mathrm{~A}_{0}\right)$. After that, $1 \mathrm{~mL}$ of hydrocarbon (xylene) was mixed separately with $3 \mathrm{~mL}$ cells suspension and pre-incubated at $37^{\circ} \mathrm{C}$ for $10 \mathrm{~min}$. The cell suspension and hydrocarbon mixture were vortexed for $2 \mathrm{~min}$ and kept for $20 \mathrm{~min}$ for phase separation (water and hydrocarbon phase). After the collection of the aqueous phase, absorbance was measured at $600 \mathrm{~nm}$ $\left(\mathrm{A}_{1}\right)$ (Equation (2)).

$$
\text { Hydrophobicity }(\%)=(1-\mathrm{A} 1 / \mathrm{A} 0) \times 100
$$

Whereas, $\mathrm{A}_{0}=$ Initial absorbance, $\mathrm{A}_{1}=$ Final absorbance

\subsubsection{DPPH Free Radical Scavenging Activity}

DPPH free radical activity of isolates was analyzed by following the method described by Chen, et al. [30]. Briefly, $100 \mu \mathrm{L}$ of freshly prepared cells $\left(10^{9} \mathrm{CFU} / \mathrm{mL}\right)$ was mixed with $1 \mathrm{~mL}$ of $(0.05 \mathrm{mM})$ DPPH solution. The mixture was mixed and kept for $30 \mathrm{~min}$ in a dark place. The absorbance was recorded at $517 \mathrm{~nm}$ and DPPH scavenging activity was calculated as given in (Equation (3)).

DPPH scavenging activity $(\%)=1-($ A sample - A blank $/$ A control $) \times 100$ 
Whereas $\mathrm{A}_{\text {sample }}=$ Bacterial cell and DPPH solution; $\mathrm{A}_{\text {blank }}=\mathrm{A}$ mixture of methanol and bacterial cells; $\mathrm{A}_{\text {control }}=\mathrm{DPPH}$ solution

\subsubsection{Resistance to Hydrogen Peroxide}

The resistance of isolates to hydrogen peroxide was determined by a modified method described by Oberg, et al. [31]. $10 \mathrm{~mL}$ of freshly prepared culture were mixed with $10 \mathrm{~mL} 0.85 \%(\mathrm{w} / \mathrm{v}) \mathrm{NaCl}$ in different test tubes with varying concentrations of $\mathrm{H}_{2} \mathrm{O}_{2}(0.5,1.0$ and $1.5 \mathrm{mM})$. The viability of isolates was determined by withdrawing samples after $60 \mathrm{~min}$ of incubation.

\subsubsection{Depletion of Sodium Nitrite}

The depletion of sodium nitrite by isolates was documented by following the method as described by $\mathrm{Wu}$, et al. [32] with minor changes. $1 \mathrm{~mL}(1500 \mu \mathrm{g} / \mathrm{mL})$ of sterilized sodium nitrite solution was mixed with $9 \mathrm{~mL}$ of MRS broth (pH 6.5) to making it $150 \mu \mathrm{g} / \mathrm{mL} .100 \mu \mathrm{L}$ freshly prepared bacterial culture $\left(10^{9} \mathrm{CFU} / \mathrm{mL}\right)$ was inoculated and incubated anaerobically for $48 \mathrm{~h}$ at $37^{\circ} \mathrm{C}$. In the case of control samples, sterile water was used instead of inoculum. The colorimetric nitrite method was used to measure initial and final absorbance at $538 \mathrm{~nm}$ by following the method described by Yan, et al. [33]. $5 \mathrm{~mL}$ of a mixture containing (inoculum, MRS broth, nitrite) was deproteinated and defatted by using $10 \mathrm{~mL}$ of $\mathrm{ZnSO}_{4}(0.42 \mathrm{~mol} / \mathrm{L})$, then the mixture was filtered. $1 \mathrm{~mL}$ of each these three-color developing solutions $(0.2 \%(\mathrm{w} / \mathrm{v})$ sulfanilamide, $0.1 \%(\mathrm{w} / \mathrm{v}) \mathrm{N}-1$-naphtyethylene diamine dihydrochloride and $44.5 \%(\mathrm{v} / \mathrm{v}) \mathrm{HCl})$ were added in filtrate and mixed it well. The mixture was kept in dark place at $37^{\circ} \mathrm{C}$ for $5 \mathrm{~min}$. The optical density of the color mixture was recorded at $538 \mathrm{~nm}$ against a blank. $3000 \mu \mathrm{g} / \mathrm{mL}$ standard sodium nitrite solution was prepared and a standard curve was constructed by following the same protocol (Equation (4)).

$$
\text { Nitrite depletion }(\%)=(1-\mathrm{Ci} / \mathrm{Cf}) \times 100
$$

Whereas, $C_{i}=$ Amount of nitrite present in MRS broth at $0 \mathrm{~h} ; \mathrm{C}_{\mathrm{f}}=$ Amount of nitrite present in MRS broth after $48 \mathrm{~h}$.

\subsubsection{Antibacterial Activity}

Antibacterial activity of isolates against three human pathogens i.e., Escherichia coli ATCC 25922, Salmonella typhimurium ATCC 14,028 and Staphylococcus aureus ATCC 25,923 were determined through ager well diffusion method [10]. $1 \mathrm{~mL}$ of the freshly prepared cells of each isolate was filtered by using a $0.2 \mu \mathrm{m}$ syringe filter. Each indicator pathogen was overlaid on Muller Hinton agar plates. $50 \mu \mathrm{L}$ of culture filtrate (cell-free supernatant) was poured into $7 \mathrm{~mm}$ diameter wells created with borer. The plates were incubated at $37^{\circ} \mathrm{C}$ for $24 \mathrm{~h}$. The clear zone diameter of each isolate against each indicator pathogen was measured after incubation. The diameter of clear zone was described as: no inhibition ( $0 \mathrm{~mm}$ ), diameter between 0-3 $\mathrm{mm}$ (weak inhibition), diameter between 3-6 $\mathrm{mm}$ (good inhibition) and diameter greater than $6 \mathrm{~mm}$ (strong inhibition) [10].

\subsubsection{Cholesterol Reduction Assay}

Cholesterol stock solution was prepared by dissolving $30 \mathrm{mg}$ of water-soluble cholesterol (polyoxyethanyl-cholesterol sebacate) in $10 \mathrm{~mL}$ distilled water and filtered $(0.45 \mu \mathrm{m})$. MRS broth containing $100 \mu \mathrm{L} / \mathrm{mL}$ cholesterol stock and $0.30 \mathrm{~g} / 100 \mathrm{~mL}$ bile salt (oxgall) was inoculated with $1 \%$ of freshly prepared culture and incubated $\left(37^{\circ} \mathrm{C}\right.$ for $\left.24 \mathrm{~h}\right)$. The samples were withdrawn after a predetermined time interval $\left(6,12\right.$, and $24 \mathrm{~h}$ ) and centrifuged $\left(4000 \times \mathrm{g}\right.$, at $4{ }^{\circ} \mathrm{C}$ for $\left.10 \mathrm{~min}\right)$. The supernatant was used to determine cholesterol content by using modified colorimetric method Rudel and Morris [34] with slight modification [35]. $2 \mathrm{~mL}$ of this supernatant was mixed with $2 \mathrm{~mL}$ $(33 \% \mathrm{w} / \mathrm{v}) \mathrm{KOH}$ and $2 \mathrm{~mL}$ ethanol $(96 \%)$. This mixture was vortexed for $2 \mathrm{~min}$, incubated at $37^{\circ} \mathrm{C}$ for $30 \mathrm{~min}$ and cooled to room temperature. After co40oling, $3 \mathrm{~mL}$ of hexane and $2 \mathrm{~mL}$ of Milli-Q 
water was added and vortexed for $2 \mathrm{~min}$. The mixture was kept for separation of two phases, hexane layer was separated (upper layer) and evaporated. $2 \mathrm{~mL}$ of o-phthalaldehyde reagent (50 mg OPA dissolved in $100 \mathrm{~mL}$ glacial acetic acid) was added and vortexed for $2 \mathrm{~min}$. $0.5 \mathrm{~mL} \mathrm{H}_{2} \mathrm{SO}_{4}(98 \%$ purity) was added into this mixture and vortexed. After $10 \mathrm{~min}$ rest at room temperature, absorbance was recorded at $550 \mathrm{~nm}$. Cholesterol removal (\%) was calculated as given in Equation (5).

$$
\text { Cholesterol removed }(\%)=\left\{\frac{100-\text { residual cholesterol after } 24 \mathrm{~h} \text { of incubation }}{100}\right\} \times 100
$$

\subsection{Safety Evaluation of Isolates}

\subsubsection{Antibiotic Susceptibility}

The antibiotic susceptibility of isolates was tested against selected antibiotics (ampicillin, cephalothin, chloramphenicol, cloxacillin, erythromycin, nalidixic acid, fusidic acid, polymyxin $B$, neomycin, streptomycin, gentamicin, rifampicin, kanamycin, novobiocin, penicillin, spectinomycin, tetracycline and vancomycin) by using antibiotic disc diffusion method on MRS agar plates as described by Vijayakumar, et al. [36]. MRS agar plates were prepared by swabbing the overnight culture of tested isolates. Antibiotic discs were placed on solidified MRS agar and give them 30 min for antibiotic diffusion and after that incubated $\left(37^{\circ} \mathrm{C}\right.$ for $\left.48 \mathrm{~h}\right)$. The zone of inhibition was measured for each antibiotic disc after the completion of incubation. The antibiotic susceptibility was differentiated by measuring zone of inhibition i.e., $<8 \mathrm{~mm}$ resistant, $8-10 \mathrm{~mm}$ moderate and $>10 \mathrm{~mm}$ susceptibility.

\subsubsection{Hemolytic Activity}

The hemolytic activity of isolates was determined by using Columbia agar containing $5 \%(\mathrm{w} / \mathrm{v})$ sheep blood and the plates were incubated at $37^{\circ} \mathrm{C}$ for $48 \mathrm{~h}$. After incubation, the hemolytic activity of isolated strains was evaluated and classified on the basis of lysis of red blood cells in the medium around the colonies. The green zones around colonies ( $\alpha$-hemolysis), clear zones around colonies ( $\beta$-hemolysis) and no zones around colonies ( $\gamma$-hemolysis) on Columbia blood agar plates. Only strains with $\gamma$-hemolysis are considered as safe [37].

\subsubsection{Cytotoxicity}

In vitro cytotoxicity activity isolates were determined according to the procedure reported in Mohanty, et al. [38] with slight modification. The cytotoxic (anti-cancer) activity of isolated strains was carried out using 3-(4,5-dimethyl-thiazol-2-yl)-2,5-diphenyltetrazolium bromide (MTT) assay. This assay measured the development of blue formazan product as an MTT reduction by mitochondrial dehydrogenase, which is the indicator of cell viability and normal functioning of mitochondria. Briefly, exponentially growing $3 \times 10^{4}$ Caco-2 cells/well $(100 \mu \mathrm{L} /$ well $)$ were incubated in 96-well plates and cultured for $24 \mathrm{~h}$. The culture medium was removed after $24 \mathrm{~h}$ and each tested isolate $\left(10^{7} \mathrm{CFU} / \mathrm{mL}\right)$ cell-free filtrate was added to the culture medium. The Caco-2 cells were further incubated for $8 \mathrm{~h}$ and $24 \mathrm{~h}$. After incubation, the percentage of cells surviving was counted using MTT assay. MTT solution $(100 \mu \mathrm{L} / \mathrm{mL})$ was added to each well. After $2 \mathrm{~h}$ of incubation at $37^{\circ} \mathrm{C}, 100 \mu \mathrm{L}$ of dimethylsulfoxide (DMSO) was added to dissolve the blue crystals and absorbance was read. The optical density was measured at $570 \mathrm{~nm}$ using a microplate reader.

\subsection{Molecular Identification of Isolate $(B-11)$}

The selected potential probiotic Bifidobacterium isolate (B-11), that possessed most of the probiotics functional characteristics were identified on the basis of $16 \mathrm{~S}$ rRNA gene sequencing. Bacterial genomic DNA was extracted by following the phenol-chloroform extraction method as described by Martinez, et al. [39] and PCR was performed by using universal $16 \mathrm{~S}$ primers (8F and 1391R). Amplicons were electrophoresed using 1\% agarose gel and purified by QIAquick PCR purification kit (Qiagen, USA) 
and quantified using Nano Drop (ND-1000) Spectrophotometer. The gene sequencing was done by the Genomics Core Facility at Michigan State University, USA. The obtained sequence was compared and molecularly identified with the available nucleotide database from the NCBI GenBank using the BLAST search (https://blast.ncbi.nlm.nih.gov/Blast.cgi). After gene sequencing, the pure isolate was labeled as Bifidobacterium longum B-11. The obtained sequence was deposited into NCBI GenBank and allotted NCBI accession number (MH041649.1).

\subsection{Attachment of B. Longum B-11 to Rats Intestine; In Vivo Studies}

In vivo studies were carried out on 10 Sprague Dawley rats (age: 3-4 weeks; weighing 15-22 g). The rats were accommodated in the animal room of the National Institute of Food Science and Technology (NIFSAT), University of Agriculture, Faisalabad after obtaining ethical approval granted from the head of NIFSAT, University of Agriculture, Faisalabad Pakistan. During the entire period, the environment in the animal room was maintained (temperature $23 \pm 2{ }^{\circ} \mathrm{C}$; relative humidity $55 \pm 5 \%$ ) with a $12 \mathrm{~h}$ light/dark cycle. The animals were fed on normal diet and tap water ad libitum for one week before the start of the trail for adaptation and to confirm their normal growth behavior. Before the start of the experiment, animal feed and water intake were observed to be free from any contamination and pathogenic infection. Rats were randomly divided into two groups $\left(G_{0}\right.$ and $\left.G_{1}\right)$, having 5 rats in each group. $\mathrm{G}_{0}$ group were administrated with normal diet while $\mathrm{G}_{1}$ were administrated B. longum $\mathrm{B}-11$ $\left(10^{7}-10^{9} \mathrm{CFU} / \mathrm{mL}\right)$ as a single dose along with normal diet for a period of one week. Administration was achieved through intragastric gavage.

\subsection{Scanning Electron Microscopy of Rats Intestine}

After one week of oral administration of B. longum B-11, the Sprague Dawley rats were sacrificed by cervical dislocation and their intestines were removed gently. The segmented intestine was opened and washed with PBS and fixed in 4\% glutaraldehyde for $1 \mathrm{~h} \mathrm{[40].} \mathrm{The} \mathrm{dehydrated} \mathrm{samples} \mathrm{were} \mathrm{placed}$ on aluminum stubs and coated with gold-palladium [41]. Field emission scanning electron microscope (FE-SEM) (S4700, Hitachi High-Technologies Corporation, Japan) was used to observe the attachment of B. longum B-11 on the intestinal surface and micrographs were taken with the same microscope.

\subsection{Statistical Analysis}

All the experimental trials were carried out in duplicate and for each trial, analysis was performed in triplicate. The results were presented as mean \pm standard deviation (SD). The data collected in this study were analyzed statistically through a completely randomized design (CRD) using Statistix 8.1. Level of significance $(p<0.05)$ was estimated by using the analysis of variance technique (ANOVA) with two factor factorials under CRD followed by Tukey's multiple comparison test.

\subsection{Ethical Approval}

All procedures performed in studies involving animals were in accordance with the ethical standards of the institution or practice at which the studies were conducted.

\section{Results}

\subsection{Isolation and Identification of Presumptive Bifidobacterium Isolates}

A total of 35 isolates (Bifidobacterium and LAB) from raw camel milk were preliminary identified. Out of these, eight isolates (B-2, B-5, B-11, B-14, B-19, B-21, B-28 and B-33) showed an appearance of bifidobacteria on the MRS medium and selected for a further experiment on the basis of cultural, morphological, microscopic, physiological and biochemical characteristics. Most of the isolates formed white to off white, shiny round colonies on an agar plate. Preliminary characterization suggested that selected isolates were all Gram-positive, rods (V or Y) shaped, catalase-negative, non-motile and non-spore forming (Table 1). 
Table 1. Morphological, physiological and biochemical characterization of the isolates.

\begin{tabular}{|c|c|c|c|c|c|c|c|c|}
\hline \multirow{2}{*}{ Tests } & \multicolumn{8}{|c|}{ Isolates } \\
\hline & B-2 & B-5 & B-11 & B-14 & B-19 & B-21 & B-28 & B-33 \\
\hline Morphology & $\begin{array}{l}\mathrm{V} \text { shaped } \\
\text { rod }\end{array}$ & rod & $\begin{array}{l}\text { Y- shaped } \\
\text { rod }\end{array}$ & $\begin{array}{l}\text { V-shaped } \\
\text { rod }\end{array}$ & rod & rod & $\begin{array}{l}\text { V-shaped } \\
\text { rod }\end{array}$ & rod \\
\hline Gram Staining & + & + & + & + & + & + & + & + \\
\hline Catalase test & - & - & - & - & - & - & - & - \\
\hline \multicolumn{9}{|l|}{$\begin{array}{l}\text { Growth at different } \\
\text { temperature }\end{array}$} \\
\hline $10^{\circ} \mathrm{C}$ & - & + & + & + & - & + & - & + \\
\hline $37^{\circ} \mathrm{C}$ & + & + & + & + & + & + & + & + \\
\hline $45^{\circ} \mathrm{C}$ & + & - & + & + & + & + & - & + \\
\hline \multicolumn{9}{|c|}{$\begin{array}{l}\text { Growth at different } \mathrm{NaCl} \\
\text { concentration }\end{array}$} \\
\hline $3 \%$ & + & + & + & + & + & + & + & + \\
\hline $5 \%$ & + & - & + & + & - & + & - & + \\
\hline $7 \%$ & + & - & - & - & - & + & - & - \\
\hline \multicolumn{9}{|l|}{ Growth at different $\mathrm{pH}$} \\
\hline 4.4 & + & + & + & + & + & + & + & + \\
\hline 9.6 & - & - & - & - & - & + & - & - \\
\hline Motility test & - & - & - & - & - & - & - & - \\
\hline Endospore test & - & - & - & - & - & - & - & - \\
\hline $\mathrm{CO}_{2}$ from glucose & - & - & - & - & - & - & - & - \\
\hline \multicolumn{9}{|c|}{ Carbohydrate fermentation } \\
\hline Glucose & + & + & + & + & + & + & + & + \\
\hline Maltose & - & + & + & - & + & + & + & + \\
\hline Lactose & + & + & + & + & + & - & - & + \\
\hline Galactose & + & + & - & - & - & + & + & + \\
\hline Raffinose & + & + & + & + & + & + & + & + \\
\hline Sorbitol & - & + & - & - & + & + & + & + \\
\hline Sucrose & + & - & + & + & - & - & - & + \\
\hline Xylose & + & + & + & - & - & + & + & + \\
\hline Fructose & + & + & + & - & + & + & + & + \\
\hline
\end{tabular}

\subsection{In Vitro Screening of Probiotic Potential of Isolates}

\subsubsection{Survival under Gastrointestinal Conditions and Phenol Tolerance}

Isolated strains have the ability to survive at $\mathrm{pH} 2$ and $\mathrm{pH} 3$ during $2 \mathrm{~h}$ of incubation (Figure 1a). At $\mathrm{pH} 2$ the survival rate was lower as compared to $\mathrm{pH} 3$ for all the tested isolates. The survival rate of B-2, B-5, B-11, B-19 and B-21 remained above $60 \%$ at $\mathrm{pH} 2$ and $\mathrm{pH} 3$ during $2 \mathrm{~h}$ of incubation.

Results also revealed that B-5, B-11 and B-19 showed significantly $(p<0.05)$ high resistance to gastrointestinal conditions ( $75 \%, 85 \%$ and $77 \%$, respectively) at $\mathrm{pH} 2$. All the isolates have the ability to tolerate various concentrations of bile salt $(0.3 \%, 0.5 \%$, and $1 \%)$ during $3 \mathrm{~h}$ of incubation (Figure $1 \mathrm{~b}$ ). Maximum survival was observed at $0.3 \%$ bile salt concentration while the least was observed at $1 \%$ bile salt concentration. As the concentration of bile salt increases the survival rate decreases. The strain B-11 survived well even such a high concentration of bile salt (1\%) than any other strain. The potential of isolates to tolerate $0.4 \%$ phenol is shown in Table 2 . All the isolates have the ability to tolerate $0.4 \%$ phenol after $24 \mathrm{~h}$ of incubation. Result revealed that non-significant difference was observed in the viable cell count after $24 \mathrm{~h}$ of incubation with minimum $\log$ reduction $(<1 \log \mathrm{CFU} / \mathrm{mL})$. 

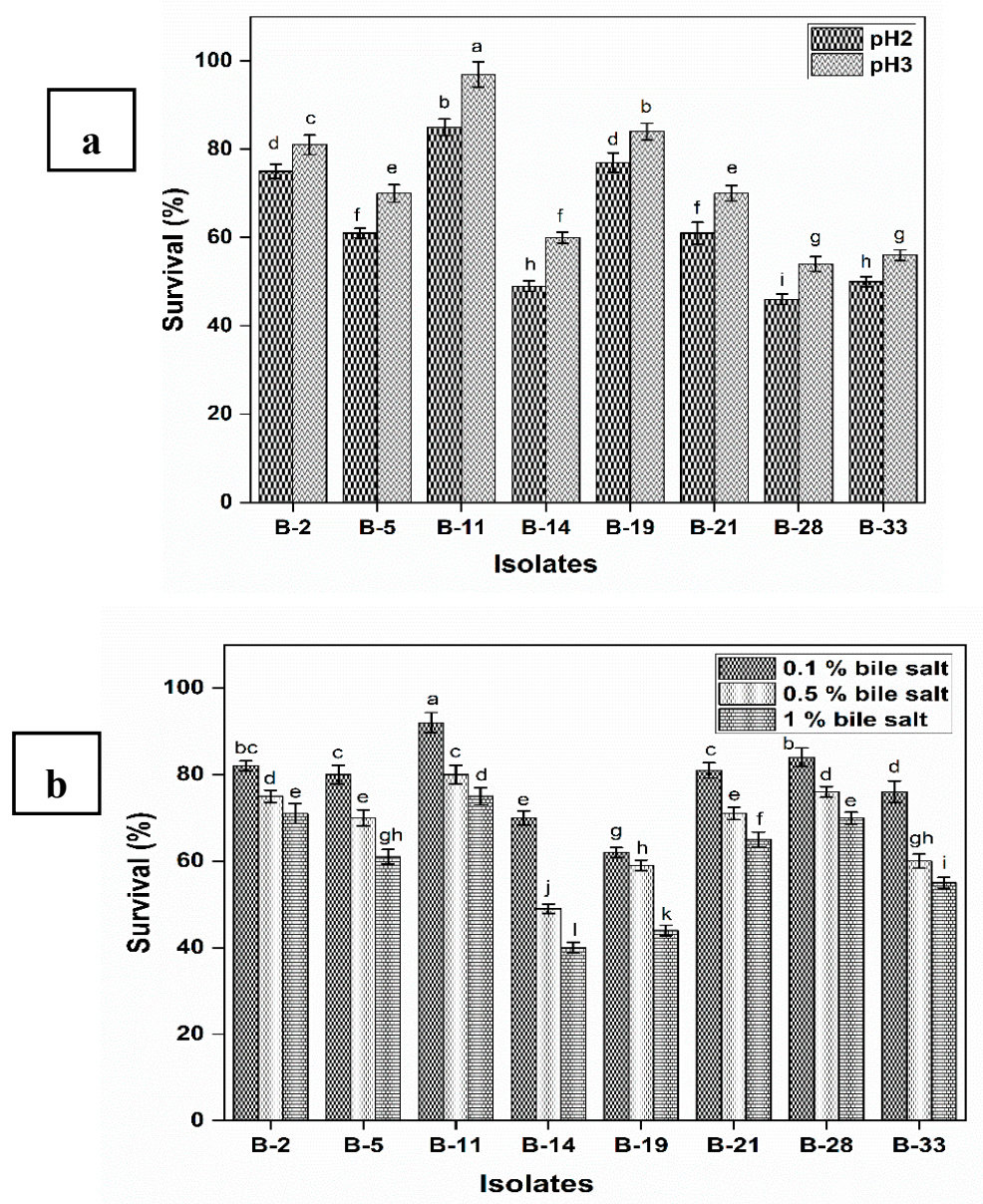

Figure 1. Survival (\%) of isolates under gastrointestinal conditions (a) Tolerance to low $\mathrm{pH}(2$ and 3) (b) Tolerance to different concentrations of bile salt i.e., $0.1 \%, 0.5 \%$ and $1 \%$. Each value represents the mean value \pm standard deviation (SD) $(n=3)$. Bars with different lower-case letters are significantly different $(p<0.05)$.

Table 2. Phenol tolerance, EPS production, Cell surface hydrophobicity, DPPH free radical scavenging activity and Depletion of sodium nitrite by the isolates (means $\pm \mathrm{SD}$ ).

\begin{tabular}{|c|c|c|c|c|c|c|}
\hline \multirow[t]{2}{*}{ Isolates } & \multicolumn{2}{|c|}{$\begin{array}{l}\text { Phenol Tolerance } \\
(\log \text { CFU/mL) }\end{array}$} & \multirow{2}{*}{$\begin{array}{c}\text { EPS } \\
\text { Production } \\
(\mathrm{mg} / \mathrm{L})\end{array}$} & \multirow{2}{*}{$\begin{array}{c}\text { Cell Surface } \\
\text { Hydrophobicity } \\
(\%)\end{array}$} & \multirow{2}{*}{$\begin{array}{c}\text { DPPH Free Radical } \\
\text { Scavenging Activity } \\
(\%)\end{array}$} & \multirow{2}{*}{$\begin{array}{c}\text { Depletion of } \\
\text { Sodium Nitrite } \\
(\%)\end{array}$} \\
\hline & $\mathrm{Oh}$ & $24 \mathrm{~h}$ & & & & \\
\hline B-2 & $8.65 \pm 0.14$ & $8.32 \pm 0.14$ & $91 \pm 2.41$ & $56.89 \pm 1.59$ & $80.29 \pm 3.12$ & $65 \pm 0.08$ \\
\hline B-5 & $8.32 \pm 0.43$ & $8.21 \pm 0.23$ & $112 \pm 2.53$ & $74.21 \pm 3.12$ & $84.44 \pm 2.93$ & $76 \pm 0.14$ \\
\hline B-11 & $8.54 \pm 0.56$ & $8.45 \pm 0.41$ & $123 \pm 3.92$ & $78.89 \pm 2.43$ & $87.72 \pm 3.01$ & $84 \pm 0.13$ \\
\hline B-14 & $8.92 \pm 0.80$ & $8.12 \pm 0.17$ & $80 \pm 2.02$ & $45.21 \pm 0.91$ & $41.38 \pm 0.42$ & $54 \pm 0.19$ \\
\hline B-19 & $8.46 \pm 0.21$ & $7.94 \pm 0.21$ & $56 \pm 1.34$ & $67.93 \pm 1.25$ & $70.23 \pm 1.40$ & $74 \pm 0.13$ \\
\hline B-21 & $8.53 \pm 0.11$ & $8.39 \pm 0.19$ & $102 \pm 2.10$ & $49.34 \pm 2.51$ & $79.74 \pm 2.52$ & $50 \pm 0.09$ \\
\hline B-28 & $7.91 \pm 0.14$ & $7.59 \pm 0.10$ & $61 \pm 3.21$ & $71.99 \pm 2.13$ & $81.19 \pm 2.16$ & $79 \pm 0.31$ \\
\hline B-33 & $8.12 \pm 0.10$ & $7.98 \pm 0.34$ & $75 \pm 2.37$ & $60.77 \pm 1.76$ & $80.72 \pm 2.34$ & $69 \pm 0.56$ \\
\hline
\end{tabular}

\subsubsection{Production of Exopolysaccharides (EPS)}

The potential of isolates to produce EPS was shown in Table 2. All the isolates were able to produce EPS but each strain exhibited different EPS production capacities. All the tested isolates had the ability to produce exopolysaccharides when grown on MRS agar supplemented with $2 \%(\mathrm{v} / \mathrm{v})$ glucose as a carbon source. Among the isolates, B-11 produced the highest EPS (123 mg/L) followed by B-5 (112 mg/L) and B-21 (102 mg/L), while the least production was observed in B-19 (56 mg/L) and B-28 (61 mg/L). 


\subsubsection{Auto-Aggregation Assay}

Cell surface traits (auto-aggregation and cell surface hydrophobicity) of probiotics are imperative for bacterial colonization and protection. All the tested isolates had high auto-aggregation activity. The isolate B-11, B-21 showed maximum auto-aggregation (65\% and 60\%) while the least was observed in B-33 (44\%). However, auto-aggregation increases as the incubation time increases, so all the isolates showed an increase in auto-aggregation after $24 \mathrm{~h}$ of incubation (Figure 2).

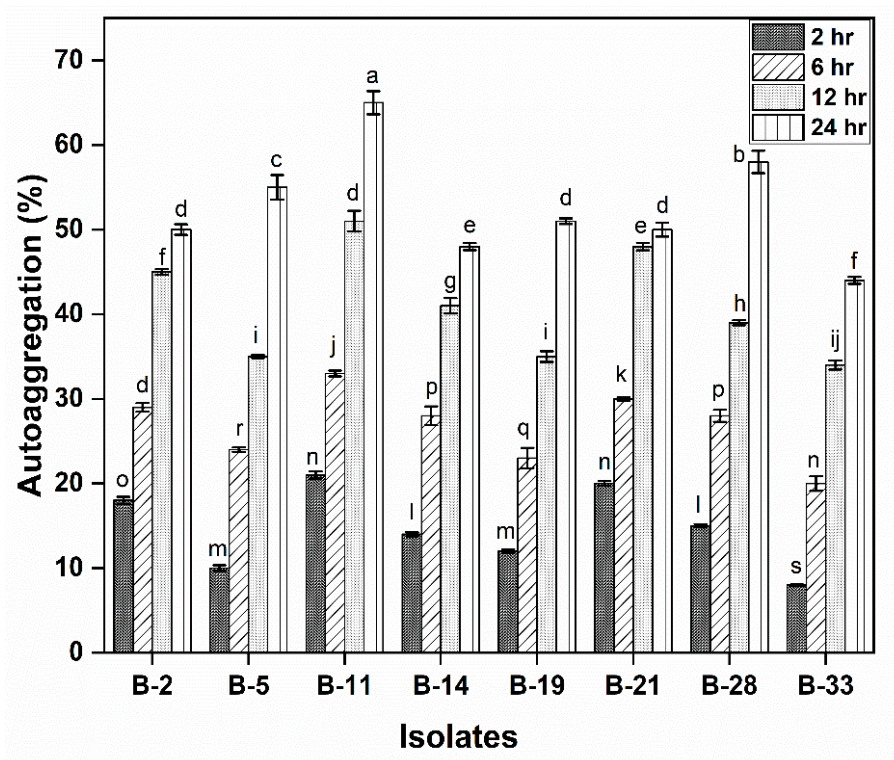

Figure 2. Autoaggregation (\%) of isolates is calculated after $2 \mathrm{~h}, 6 \mathrm{~h}, 12 \mathrm{~h}$ and $24 \mathrm{~h}$ of incubation. Each value represents the mean value \pm standard deviation (SD) $(n=3)$. Bars with different lower-case letters denoted significantly different $(p<0.05)$.

\subsubsection{Cell Surface Hydrophobicity}

The isolates B-11, B-5, B-28, B-19, and B-33 had high cell surface hydrophobicity $(78.89 \%, 74.21 \%$, $71.99 \%, 67.93 \%$, and $60.77 \%$ ) as compared to other isolates. However, isolate B-14 had the lowest hydrophobicity (45.21\%) (Table 2 ).

\subsubsection{DPPH Free Radical Scavenging Activity}

isolate $\mathrm{b}-11$ had the highest dpph scavenging ability $(87.72 \%)$, followed by b-5 (84.44\%), b-28 (81.19\%), b-2 (80.29\%), b-33 (80.72\%), b-21 (79.74\%) and b-19 (70.23\%) (Table 2).

\subsubsection{Resistance to Hydrogen Peroxide}

All the tested isolates have the ability to resist $\mathrm{H}_{2} \mathrm{O}_{2}$. Results revealed that a significant impact on the viability of isolates was observed as the concentration of $\mathrm{H}_{2} \mathrm{O}_{2}$ increases exhibiting a decreasing trend. B-11 showed that the maximum viable cells count $(8.1 \log \mathrm{CFU} / \mathrm{mL})$ while the least was observed in B-33 (5.45 $\log \mathrm{CFU} / \mathrm{mL})$ at $1.5 \mathrm{mM} \mathrm{H}_{2} \mathrm{O}_{2}$ (Figure 3). In the case of B-2, B-5, B-14, B-19 and B-21 the viable cell count was $>10^{6} \log \mathrm{CFU} / \mathrm{mL}$. 


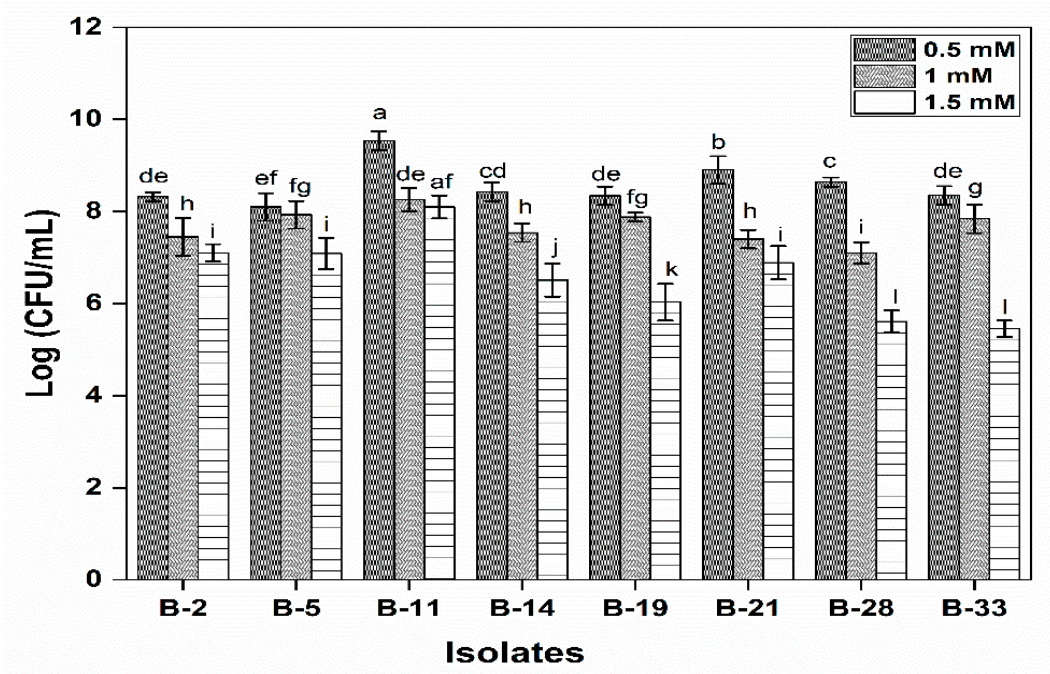

Figure 3. Resistance to hydrogen peroxide is determined by calculating the bacterial count of isolates at different concentration of hydrogen peroxide i.e., $0.5 \mathrm{mM}, 1 \mathrm{mM}$ and $1.5 \mathrm{mM}$. Each value represents the mean value \pm standard deviation (SD) $(n=3)$. Bars with different lower-case letters denoted significantly different $(p<0.05)$.

\subsubsection{Depletion of Sodium Nitrite}

Nitrite is used as an additive in a number of fermented products. It is still considered undesirable in food products due to its safety concerns. It is recognized as a carcinogenic and teratogenic substance due to its high oxidative and reductive activities. There is a need to eliminate nitrite during fermentation. The results propounded in Table 2 revealed that all isolates had the ability to deplete nitrite. Among the isolates, B-11 depleted maximum nitrite $84 \%$ followed by B-5 $(76 \%)$ while the least nitrite depletion was observed in B-21 (50\%).

\subsubsection{Antibacterial Activity}

The results of the antibacterial activity as a halo of growth inhibition produced on agar plates by tested isolates against indicator pathogens were presented in Table 3. Isolates exhibited strong antimicrobial activity against pathogenic bacteria (Escherichia coli, Salmonella typhimurium and Staphylococcus aureus). Most of the isolates inhibited indicator pathogenic bacteria and the zone of inhibition was $>6 \mathrm{~mm}$. The isolates B-19 and B-28 exhibited zero inhibition against Escheria coli and Salmonella typhimurium, respectively. The observed inhibitory property of the isolates could be attributed due to the production of antimicrobial compounds. Based on the results, E. coli and Salmonella typhimurium were the most sensitive and S. aureus was the most resistant indicator bacteria against the tested isolates.

Table 3. Antibacterial activity of isolates (means \pm SD).

\begin{tabular}{cccc}
\hline \multicolumn{3}{c}{ Zone of Inhibition } \\
\hline Isolates & $\begin{array}{c}\text { Staphylococcus aureus } \\
(\mathbf{m m})\end{array}$ & $\begin{array}{c}\text { Salmonella } \\
\text { typhimurium } \mathbf{( m m})\end{array}$ & Escherichia coli $(\mathbf{m m})$ \\
\hline B-2 & $8 \pm 0.51$ & $8 \pm 0.11$ & $7 \pm 0.26$ \\
B-5 & $10 \pm 0.42$ & $7 \pm 0.09$ & $10 \pm 0.21$ \\
B-11 & $11 \pm 0.35$ & $12 \pm 0.12$ & $14 \pm 0.13$ \\
B-14 & $8 \pm 0.14$ & $10 \pm 0.21$ & $11 \pm 0.12$ \\
B-19 & $8 \pm 0.21$ & $9 \pm 0.08$ & $0 \pm 0.27$ \\
B-21 & $7 \pm 0.28$ & $10 \pm 0.12$ & $6 \pm 0.06$ \\
B-28 & $9 \pm 0.17$ & $0 \pm 0.10$ & $8 \pm 0.15$ \\
B-33 & $6 \pm 0.06$ & $6 \pm 0.04$ & $9 \pm 0.19$ \\
\hline
\end{tabular}

Where, no inhibition diameter equal to $0 \mathrm{~mm}$; weak inhibition, diameter between 0-3 $\mathrm{mm}$; good inhibition, diameter between 3-6 mm; strong inhibition, greater than $6 \mathrm{~mm}$. 


\subsubsection{Cholesterol Reduction Assay}

The removal of cholesterol by 8 probiotics bacterial strains grown on MRS broth supplemented with $0.3 \%$ oxgal was presented in Figure 4 . All the tested isolates were able to assimilate cholesterol. Results revealed that cholesterol removal varied significantly $(p<0.05)$ among all the isolates at the same incubation time i.e., $6 \mathrm{~h}, 12 \mathrm{~h}$ and $24 \mathrm{~h}$. Probiotic strains B-2, B-5, B-11 and B-21 showed significantly $(p<0.05)$ high cholesterol removal $(60 \%, 54 \%, 71 \%$ and 51\%, respectively) after 24 h of incubation as compare to other isolates. The lowest cholesterol removal ability was observed in isolate B-28 (38\%) and B-33 (33\%). The cholesterol removal ability increases as the incubation time increases.

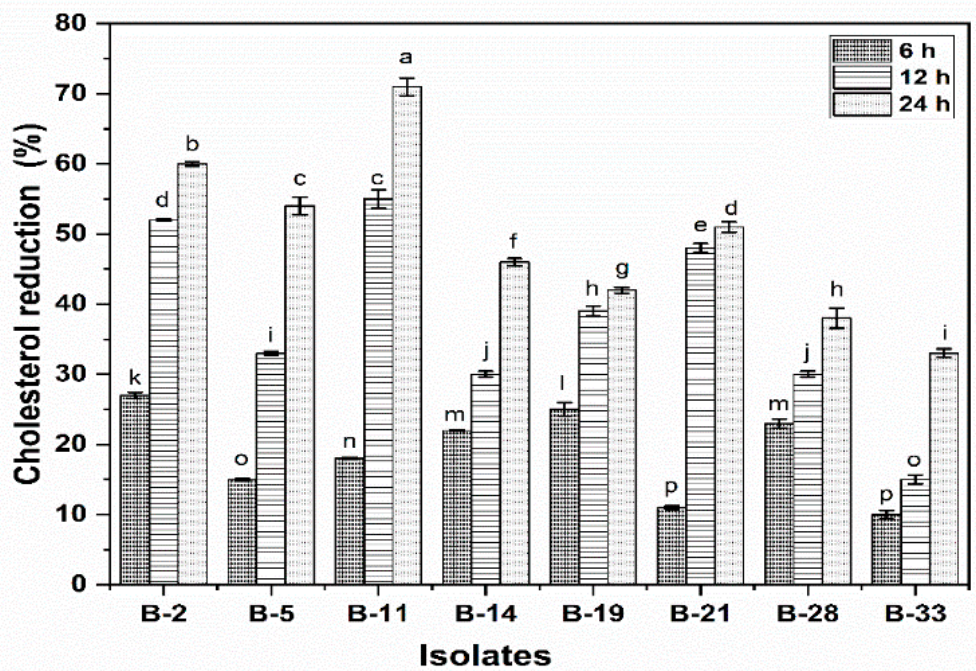

Figure 4. Cholesterol reduction (\%) of isolates after $6 \mathrm{~h}, 12 \mathrm{~h}$ and $24 \mathrm{~h}$ of incubation. Each value represents the mean value \pm standard deviation (SD) $(n=3)$. Bars with different lower-case letters denoted significantly different $(p<0.05)$.

\subsection{Safety Evaluation of Isolates}

\subsubsection{Antibiotics Susceptibility}

The antibiotic susceptibility of the tested isolates was documented by using different commonly used antibiotics. Results presented in Table 4 revealed that all the isolates were resistant to nalidixic acid, fusidic acid, polymyxin B, neomycin, streptomycin, gentamicin, rifampicin and kanamycin except B-14 which exhibited sensitivity to neomycin, B-21 was sensitive to rifampicin and streptomycin, respectively.

Table 4. Antibiotic susceptibility of isolates.

\begin{tabular}{cccccccccc}
\hline Antibiotics & Disc Potency $\mathbf{( \mu g )}$ & B-2 & B-5 & B-11 & B-14 & B-19 & B-21 & B-28 & B-33 \\
\hline Ampicillin & 10 & $\mathrm{~S}$ & $\mathrm{~S}$ & $\mathrm{~S}$ & $\mathrm{~S}$ & $\mathrm{~S}$ & $\mathrm{~S}$ & $\mathrm{~S}$ & $\mathrm{~S}$ \\
Cephalothin & 15 & $\mathrm{~S}$ & $\mathrm{~S}$ & $\mathrm{~S}$ & $\mathrm{~S}$ & $\mathrm{~S}$ & $\mathrm{~S}$ & $\mathrm{~S}$ & $\mathrm{~S}$ \\
Chloramphenicol & 50 & $\mathrm{~S}$ & $\mathrm{~S}$ & $\mathrm{~S}$ & $\mathrm{~S}$ & $\mathrm{~S}$ & $\mathrm{~S}$ & $\mathrm{~S}$ & $\mathrm{~S}$ \\
Cloxacillin & 20 & $\mathrm{~S}$ & $\mathrm{~S}$ & $\mathrm{~S}$ & $\mathrm{~S}$ & $\mathrm{~S}$ & $\mathrm{~S}$ & $\mathrm{~S}$ & $\mathrm{~S}$ \\
Erythromycin & 10 & $\mathrm{~S}$ & $\mathrm{~S}$ & $\mathrm{~S}$ & $\mathrm{~S}$ & $\mathrm{~S}$ & $\mathrm{~S}$ & $\mathrm{~S}$ & $\mathrm{~S}$ \\
Fusidic acid & 10 & $\mathrm{R}$ & $\mathrm{R}$ & $\mathrm{R}$ & $\mathrm{R}$ & $\mathrm{R}$ & $\mathrm{R}$ & $\mathrm{R}$ & $\mathrm{R}$ \\
Gentamicin & 10 & $\mathrm{R}$ & $\mathrm{R}$ & $\mathrm{R}$ & $\mathrm{R}$ & $\mathrm{R}$ & $\mathrm{R}$ & $\mathrm{R}$ & $\mathrm{R}$ \\
Kanamycin & 30 & $\mathrm{R}$ & $\mathrm{R}$ & $\mathrm{R}$ & $\mathrm{R}$ & $\mathrm{R}$ & $\mathrm{R}$ & $\mathrm{R}$ & $\mathrm{R}$ \\
Nalidixic acid & 20 & $\mathrm{R}$ & $\mathrm{R}$ & $\mathrm{R}$ & $\mathrm{R}$ & $\mathrm{R}$ & $\mathrm{R}$ & $\mathrm{R}$ & $\mathrm{R}$ \\
Neomycin & 20 & $\mathrm{R}$ & $\mathrm{R}$ & $\mathrm{R}$ & $\mathrm{S}$ & $\mathrm{R}$ & $\mathrm{R}$ & $\mathrm{R}$ & $\mathrm{R}$ \\
Novobiocin & 30 & $\mathrm{~S}$ & $\mathrm{~S}$ & $\mathrm{~S}$ & $\mathrm{~S}$ & $\mathrm{~S}$ & $\mathrm{~S}$ & $\mathrm{~S}$ & $\mathrm{~S}$ \\
Penicillin & 10 & $\mathrm{~S}$ & $\mathrm{~S}$ & $\mathrm{~S}$ & $\mathrm{~S}$ & $\mathrm{~S}$ & $\mathrm{~S}$ & $\mathrm{~S}$ & $\mathrm{~S}$ \\
Polymyxin B & 20 & $\mathrm{R}$ & $\mathrm{R}$ & $\mathrm{R}$ & $\mathrm{R}$ & $\mathrm{R}$ & $\mathrm{R}$ & $\mathrm{R}$ & $\mathrm{R}$ \\
Rifampicin & 20 & $\mathrm{R}$ & $\mathrm{R}$ & $\mathrm{R}$ & $\mathrm{R}$ & $\mathrm{R}$ & $\mathrm{S}$ & $\mathrm{R}$ & $\mathrm{R}$ \\
Spectinomycin & 10 & $\mathrm{~S}$ & $\mathrm{~S}$ & $\mathrm{~S}$ & $\mathrm{~S}$ & $\mathrm{~S}$ & $\mathrm{~S}$ & $\mathrm{~S}$ & $\mathrm{~S}$ \\
Streptomycin & 25 & $\mathrm{R}$ & $\mathrm{R}$ & $\mathrm{R}$ & $\mathrm{R}$ & $\mathrm{R}$ & $\mathrm{S}$ & $\mathrm{R}$ & $\mathrm{R}$ \\
Tetracycline & 30 & $\mathrm{~S}$ & $\mathrm{~S}$ & $\mathrm{~S}$ & $\mathrm{~S}$ & $\mathrm{~S}$ & $\mathrm{~S}$ & $\mathrm{~S}$ & $\mathrm{~S}$ \\
Vancomycin & 30 & $\mathrm{~S}$ & $\mathrm{~S}$ & $\mathrm{~S}$ & $\mathrm{~S}$ & $\mathrm{~S}$ & $\mathrm{~S}$ & $\mathrm{~S}$ & $\mathrm{~S}$ \\
\hline
\end{tabular}

Where, inhibition zone diameter $<8 \mathrm{~mm}$, resistant (R); inhibition zone diameter between $8-10 \mathrm{~mm}$, moderate (M) and inhibition zone diameter $>10 \mathrm{~mm}$, susceptibility (S). 


\subsubsection{Hemolytic Activity}

Hemolytic activities of 8 tested isolated were evaluated on blood agar plates. None of the tested strains showed $\alpha$-hemolytic and $\beta$-hemolytic activity when grown on Columbia blood agar plates. The tested strains showed $\gamma$ hemolytic, i.e., negative, or no hemolytic activity.

\subsubsection{Cytotoxicity}

In this experiment, MTT [3-(4,5-Dimethylthiazol-2-yl)-2,5-diphenyltetrazolium bromide] assay was used to observe the effect of different isolates on Caco-2 cell viability. The results showed that all the tested isolates did not significantly damage cells after $8 \mathrm{~h}$ of incubation however, $24 \mathrm{~h}$ of incubation harmed the cells and cells lost their viability. There was no significant difference in cell viability of B-11 after $24 \mathrm{~h}$ of incubation (Figure 5). Furthermore, least damage was observed in the case of B-14, B-19 and B-21 after $24 \mathrm{~h}$ of incubation. Therefore, the probiotic treatment showed insignificant changes among all the tested isolates in the culture supernatant of Caco-2 cells, keeping the membrane integrity during probiotic exposure after $8 \mathrm{~h}$ but the viability decreases significantly between 8 to $24 \mathrm{~h}$.

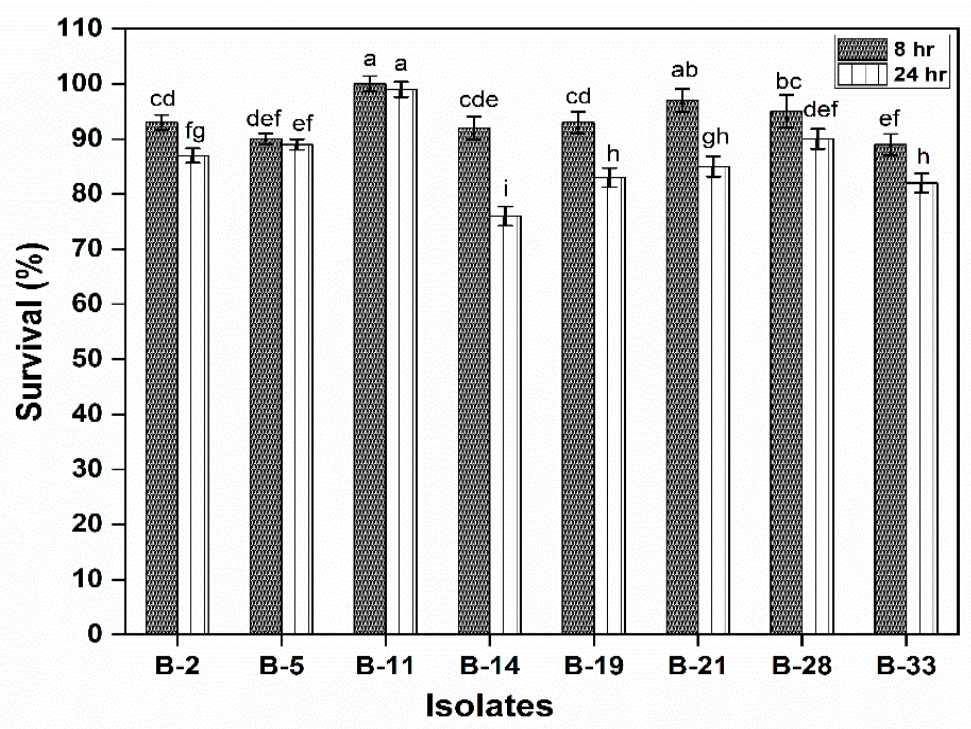

Figure 5. Cytotoxicity to observed the survival (\%) of isolates after $8 \mathrm{~h}$ and $24 \mathrm{~h}$ of incubation. Each value represents the mean value \pm standard deviation (SD) $(n=3)$. Bars with different lower-case letters denoted significantly different $(p<0.05)$.

\subsection{Molecular Identification of Isolate (B-11)}

Considering that among all the isolates, B-11 possessed most of the probiotic's attributes. The isolate was further confirmed through $16 \mathrm{~S}$ rRNA gene sequence analysis. On the basis of molecular identification, purified PCR products were sequenced and compared with the information in the NCBI database. BLAST search disclosed that isolated bacterium as B. longum subsp. longum which exhibited a similarity index $(100 \%)$ to other B. longum strains. Therefore, the isolate was a strain of B. longum and designated as B. longum B-11. The $16 \mathrm{~S}$ rRNA sequence was deposited to NCBI Genebank data base under the accession number MH041649.1.

\subsection{Scanning Electron Microscopy of Rat Intestine}

Scanning electron microscopy images revealed that small intestine of rat (control group, $\mathrm{G}_{0}$ ) showed a large number of coccus shaped bacterial attachment on the upper surface (Figure 6a), while the rats treated with $B$. longum B-11 $\left(\mathrm{G}_{1}\right)$ showed presence of a large number of rods shaped bacteria (B. longum B-11). Well organized and steady microvilli can be observed in the case of B. longum B-11 treated rats (Figure $6 \mathrm{~b}, \mathrm{c}$ ). 


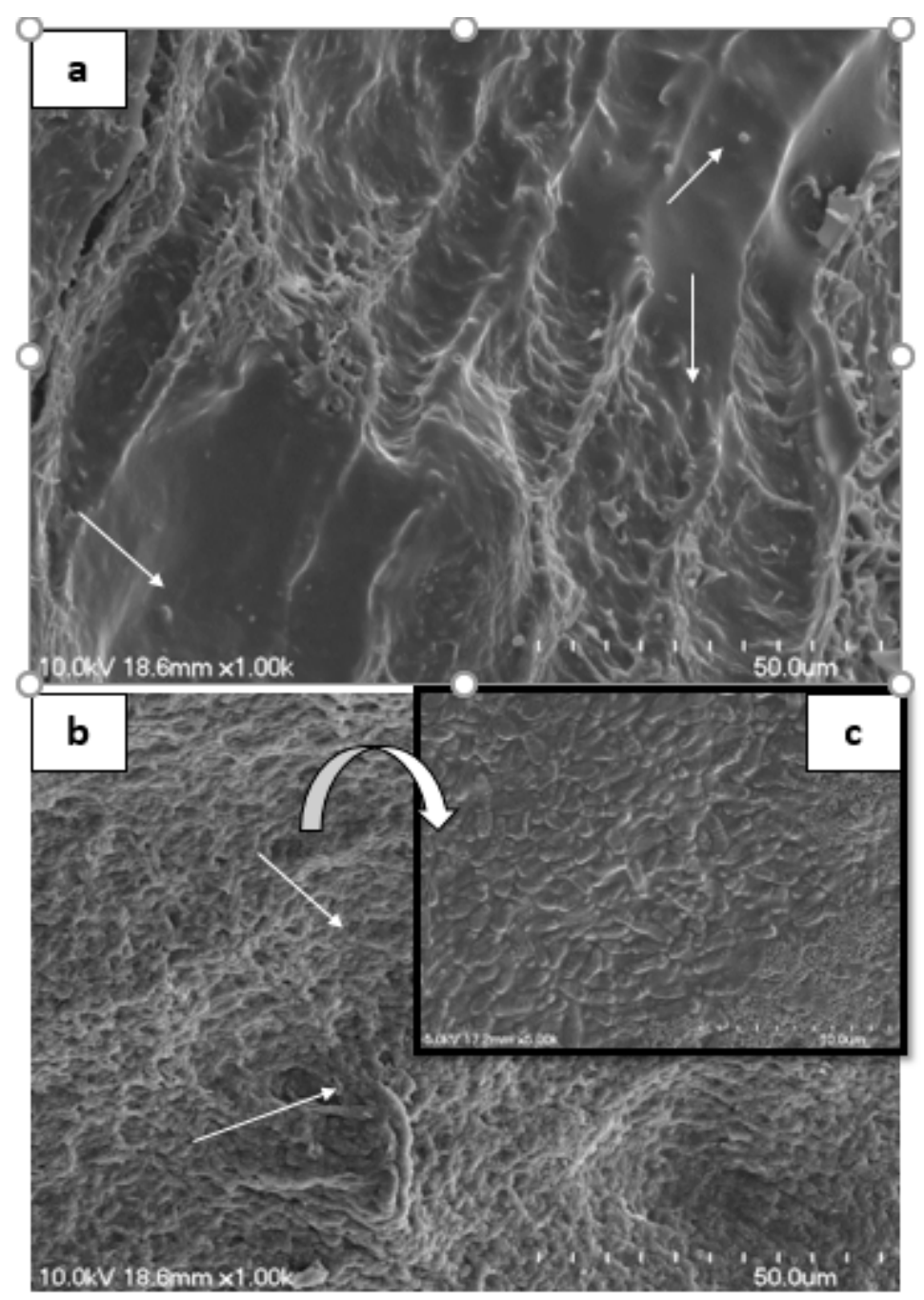

Figure 6. Scanning electron microscopy (SEM) of excised rat GIT showing presence of large number of coccus-shaped bacteria on the upper surface $\left(\mathrm{G}_{0}\right)(\mathbf{a})$. The rat administrated with B. longum B-11 displayed huge number of rods on the microvilli of GIT $\left(\mathrm{G}_{1}\right)(\mathbf{b})$. Magnified images of B. longum B-11 showing bacterial cell are V or Y shaped rods (c).

\section{Discussion}

In the present study, 35 colonies were isolated from camel milk and eight (B-2, B-5, B-11, B-14, B-19, B-21, B-28, B-33) was identified as bifidobacteria on the basis of morphology, physiology and biochemical characterization. Studies revealed that Bifidobacterium was Gram-positive, rods (V or Y) shaped, catalase-negative, non-motile and non-spore forming [4].

The probiotic potential of isolates was assessed through their survival ability under the artificial simulated conditions in the digestive tract. Various researchers contributed their work in this field to evaluate potentially probiotic strains. $\mathrm{pH}$ is an important parameter that affects the growth and viability of probiotics during gastric transit. Among eight isolates, three isolates (B-2, B-11, B-19) showed survival rate in the range of (75-85\%) at $\mathrm{pH} 2$ and more than $90 \%$ at $\mathrm{pH} 3$ after $2 \mathrm{~h}$ of exposure. The survival rate is higher as compared to previously reported Bifidobacterium strains under such low $\mathrm{pH}[42,43]$.

Probiotics should survive in the gastrointestinal conditions and reach alive in the small intestine, where they colonize and impart positive health benefits to the host. The decreased in the viability and survival is due to the presence of pepsin enzymes and low $\mathrm{pH}$ of gastric juice [44]. The probiotics should with stand harsh gastrointestinal conditions (gastric juice and bile salt) to exert positive health 
benefits to humans. Gastric juice and bile salt-resistance is considering one of the prime criteria in the selection of probiotics [45]. B. longum strains presented maximum viability in GIT as compared to other species belonging to the same genera [42].

All the isolates exhibited more than $70 \%$ survival rate at $0.1 \%(\mathrm{w} / \mathrm{v})$ bile salt concentration except B-19. Three isolates (B-2, B-11, B-28) showed a survival rate in the range of (70-75\%) at such a high concentration of bile salt (1\%). Sanchez, et al. [46] studied the probiotic potential of different B. longum strains (mutant and wild type) at different bile salt concentrations $(0.5 \%, 1 \%, 2 \%$ and $3 \%$ ) and expounded that viability of $B$. longum decreased as bile salt concentration increased. Mutant strains indicated viability at $0.5 \%$ to $3 \%$ bile salt concentration while the wild type was not able to grow at such a high concentration of bile salt. Haros, et al. [47] investigated tolerance of B. pseudocatenulatum to $(0.5-2 \%)$ bile salt and reported that Bifidobacterium strain was resistant to bile salt even after $4 \mathrm{~h}$ of incubation. Ren, Li, Qin, Yin, Du, Ye, Liu, Liu, Wang, Li, Sun, Li, Tian and Jin [10] demarcated similar results for bile salt tolerance at $0.3 \%$ to $0.5 \%$ concentration. Even most of the probiotic strains showed resistance to $1 \%$ bile salt, which is approximately three times the bile concentration in the human intestine. Haghshenas, et al. [48] observed tolerance to bile salt but survival decreased as a function of incubation time. In the current study, all isolates have the ability to tolerate high phenol concentration $(0.4 \%)$, revealed that they can tolerate the bacteriostatic effect of phenol in GIT. Phenol is actually the by-product of metabolism of aromatic amino acids that produce in the gut.

Exopolysaccharide production is important for protection, colonization and acts as intermediaries to establish an association between bacteria and host [49]. All the isolates were able to produce EPS. Among Bifidobacterium strains, B. longum is the most frequently cited probiotics due to the comparatively high yield of EPS being produced. Prasanna, et al. [50] screened various Bifidobacterium strains and reported that among all the Bifidobacterium strains, B. longum subsp. infantis CCUG 52,486 was the highest EPS producing strain $(138 \mathrm{mg} / \mathrm{L})$. The capsular structure of EPS protects probiotics from harsh gastrointestinal conditions like gastric juice, bile salt and etc. High yielding EPS strains could survive well in high acidic and bile salt conditions. In this way, EPS promotes bacterial growth and survival in the presence of high acid and bile salt conditions [51]. EPS also serves as a growth substrate for gut microflora and provides protection against phagocytosis and bacteriophage attack.

Cell surface properties i.e., cell surface hydrophobicity and autoaggregation are important for bacterial attachment to intestinal lining and colonization in the GIT. In the current study, B-5 (74.21\%), B-11 (78.89\%) and B-28 (71.99\%) exhibited comparatively high hydrophobicity to xylene. These isolates also showed high autoaggregation B-5 (55\%) B-11 (65\%) and B-28 (58\%) after $24 \mathrm{~h}$ of incubation. $\mathrm{Xu}$, Jeong, Lee and Ahn [28] described cell surface property and reported that the highest value for hydrophobicity was found in B. longum B6 (53.6\%) followed by Lb. rhamnosus GG (46.5\%). Moreover, Rahman, et al. [52], also explored 13 strains of 4 different Bifidobacterium spp. for their auto-aggregation ability and surface hydrophobicity. They explained that among all Bifidobacterium spp. B. longum presented high cell surface hydrophobicity. Auto-aggregation ability and surface hydrophobicity are related to cell adhesion, which promotes binding of probiotics to the intestinal lining. As a result of this binding, it acts as a barrier and pathogens are unable to colonize. This adhesion of probiotics to the intestinal cell is essential for pathogen omission and immunomodulation [53]. In vitro, cell surface properties are not a reliable approach to judge their interaction within the host cell. There is still a need to study it in vivo, for a better understanding of this interaction.

Bifidobacterium has the ability to act as an antioxidant by quenching free oxygen radicles. In the current study the cell-free supernatant of B-2 (80.29\%), B-5 (84.44\%), B-11 (87.72\%), B-28 (81.19\%), B-33 (80.72\%) exhibited strong antioxidant activity as compared to other studies. Shen, et al. [54] documented the antioxidant activity of $B$. animals 01 both in vitro and in vivo. The results reported that culture supernatant exhibited the highest DPPH radical scavenging activity (73.11\%). Likewise, Wang, et al. [55] elucidated that, LAB and Bifidobacterium fermented soymilk had higher antioxidative activity than un-fermented soymilk. Nevertheless, these studies represented the antioxidative ability in vitro but there is still a need to study this activity in vivo. Synthetic antioxidants have serious health 
implications regarding their safety and long term utilization. Synthetic antioxidants i.e., butylated hydroxytoluene (BHT) and butylated hydroxyanisole (BHA) have toxic and carcinogenic effects [56]. Therefore, it is the need of the day to explore non-toxic, natural and low-cost antioxidants as a substitute for a synthetic antioxidants in pharmaceutical and food industries.

Nitrite is commonly used as a food additive and has been widely found in various food products. It is an important N-nitrosamines precursor, which potentially causes cancer and methemoglobinemia. Nitrites also react with amines (protein degradation products) to form N-nitroso compounds [10]. So, it is an important safety concern to limit the use of nitrite in food products. In this context, all the tested isolates have the ability to deplete nitrite and restrict the conversion of nitrite into nitrosamines. Although the exact mechanism is still not fully understood it might be due to enzymatic and chemical reactions. There is a need to further evaluate this in a food product.

Probiotics are helpful in the management of GIT infections. They exert positive effects against antibiotic-associated diarrhea, travel diarrhea and rotavirus. These antimicrobial substances are proteinases in nature and produced by various Bifidobacterium spp. Collado, et al. [57] explicated that antimicrobial peptides produced from Bifidobacterium strains had strong antagonist activity against both antibiotic sensitive and antibiotic-resistant pathogens. Antimicrobial peptides could be one of the effective mechanisms to combat infectious diseases.

An isolate B-11 exhibited most of the probiotics attributes and confirm through molecular identification and named as Bifidobacterium longum B-11. The obtained sequence was deposited into NCBI GenBank and allotted NCBI accession number (MH041649.1). B. longum B-11 was further selected for in vivo attachment to the intestinal lining and the results are in line with the findings of Choudhary, Dubey, Sengar and Dheeman [40]. B. longum B-11 was the potential microorganism to be used as probiotics for human consumption due to better colonization in GIT and better adhesion to the epithelial lining of the host.

High cholesterol level has several health implications i.e., high risk of cardiovascular ailments which is the major cause of death. Use of the drug in the treatment of hypercholesterolemia has numerous side effects. Therefore, it is of utmost important to use natural, cost-effective methods to reduce serum cholesterol. Consumers are more concerned to use safe and alternate products for hypercholesterolemia that limit dependence on drug therapy. In this context, the use of supplementing diets with probiotic strains is one of the effective and promising strategies to reduce serum cholesterol. The results of the current study revealed that Bifidobacterium strains have the ability to lower down the cholesterol level. B. longum B-11 exhibited maximum cholesterol removal percentage. The result of the current study is in accordance with the findings of El-Gawad, et al. [58], who evaluated that the cholesterol reduction of B. longum Bb-46 fortified buffalo milk yogurts. They fed hypercholesterolemic male albino rats with $50 \mathrm{~g}$ yoghurt containing $0.07 \%(\mathrm{w} / \mathrm{v})$ probiotics for 35 consecutive days. They delineated that probiotic fortified yoghurt significantly reduced total cholesterol level by $50.3 \%$, triglycerides by $51.2 \%$ and LDL by $56.3 \%$ as compared to control. Likewise, Xiao, et al. [59] explicated the effect of low fat yoghurt fortified with B. longum BL1 $\left(10^{8} \mathrm{CFU} / \mathrm{g}\right)$ on cholesterol level of thirty-two subjects (cholesterol level 220-280 mg/dL, aged 28-60 years old, weight $55.4-81.8 \mathrm{~kg}$ ). The results illustrated that there was a significant reduction in serum total cholesterol level, LDL cholesterol and triglycerides as compared to control after 4 weeks.

As far as safety is concerned the isolates should have the ability to resist commonly used antibiotics [10]. The literature revealed that Bifidobacterium is susceptible to antibiotics and can be consumed safely after antibiotic therapy for maintaining the balance of gut microflora. Similarly, Zhou, et al. [60] investigated that $B$. lactis strains were susceptible to erythromycin, novobiocin, rifampicin, tetracycline, spectinomycin, h-lactam, chloramphenicol, penicillin, cephalothin and ampicillin. These strains were resistant towards nalidixic acid, fusidic acid, polymyxin B, aminoglycosides, neomycin, streptomycin, gentamicin and kanamycin. Likewise, Temmerman, et al. [61] isolated B. longum from different products and evaluated that B. longum was resistant to kanamycin and susceptible to erythromycin, tetracycline, chloramphenicol, penicillin and vancomycin. 
According to the European Food Safety Authority (EFSA), the evaluation of hemolytic activity is strongly recommended if the isolated bacteria intended to use in food products, even if they have GRAS or QPS (Quality Presumption of Safety) status (FAO/WHO 2006). In this study, the hemolytic activity of 8 tested isolates was evaluated on Columbia blood agar plates. None of the tested strains showed $\alpha$-hemolytic and $\beta$-hemolytic activity when grown in Columbian sheep blood agar. All the tested strains showed $\gamma$ - hemolytic or no hemolytic activity. Our results were in agreement with the finding of Oh and Jung [62] who determined the hemolytic activity of five Lactobacillus species isolated from traditionally fermented millet-based alcoholic beverages. The results of current findings were also consistent with the results of Wang, et al. [63] who evaluated the probiotic potential of lactic acid bacteria from Chinese spontaneously fermented non-dairy food products and revealed no hemolytic activity of probiotic. Many researchers [37,64-66] reported that probiotics did not showed hemolytic activity. When the safety of probiotic is concerned, lack of hemolytic activity is important during the selection of probiotic strains, because such strains are non-virulence and lack of hemolysin ensures that virulence will not appear among the bacterial strains (FAO/WHO 2006). The enzymes production that are capable of degrading mucin is suggested as a key factor of virulence for pathogens. So that, this feature is not recommended for probiotic strains because it modifies the intestinal mucosal lining as a result mucosal invasion happens by other toxic materials and pathogens [37].

It is proved that all the tested isolates were found to have better anticancer activity with cell viability $>80 \%$ of the Caco- 2 cell. Thus, the novelty of isolates especially B- 11 has been proved for its effective anti-carcinogenic effect. Chui and coworkers reported similar results, L. plantarum co-cultured with Caco-2 cells did not affect cell viability within $10 \mathrm{~h}$, but cell viability decreased significantly between 12 and $14 \mathrm{~h}$ but the decreases was non-significant [67]. The inhibitory effects of probiotics upon the proliferation of several colon cancer cell lines have been previously demonstrated by various authors [38,68-73].

MTT assay is considered as a highly sensitive assay for determining cellular respiration, cell viability and cytotoxicity because only living cells are able to produce formazan products during this reaction. Lactobacilli and bifidobacteria are the most prominent probiotics that have been recognized as safe and increasing research interest due to their significant role in the prevention of cancer [74]. Probiotics generally modulate intestinal microflora, inactivate carcinogenic complexes, improves host's immunity, compete with pathogens, have anti-proliferative effects by regulating apoptosis and cell differentiation [68].

\section{Conclusions}

In the current study, eight potential probiotics were successfully isolated from raw camel milk according to the international probiotic guidelines. Among all the isolates, B-11 had the maximum potential for practical application due to high resistance to GIT conditions as well as strong antagonistic and antioxidant activities. B-11 also displayed antibiotic susceptibility and produced the highest EPS yield. B-11 is effective to deplete nitrite and assimilate cholesterol. Therefore, B-11 is introduced as a potential probiotic to be used safely in the development of functional food products. Moreover, in vivo studies would be needed to further evaluate its immunomodulatory, safety and health perspective as a potential probiotic.

Author Contributions: Conceptualization, I.Y. and M.S.; Data curation, A.K.; Formal analysis, I.Y., W.A.K. and S.N.; Funding acquisition, I.Y.; Investigation, T.M.; Methodology, I.Y., M.F.J.C., and R.I.; Project administration, S.T. Software, A.L., S.A. and S.T.; Validation, W.A.K.; Visualization, I.Y. and W.A.K.; Supervision, M.S.; Writing-original draft, I.Y.; Writing-review \& editing, M.S. and W.A.K. All authors have read and agreed to the published version of the manuscript.

Funding: The authors are thankful to the funding provided by the Higher Education Commission, Pakistan, through the International Research Support Initiative Program (IRSIP) to carry out this work in the Department of Food Science and Technology, University of Nebraska, Lincoln, USA.

Conflicts of Interest: The authors declare that they have no conflict of interest. 


\section{References}

1. García-Ruiz, A.; de Llano, D.G.; Esteban-Fernández, A.; Requena, T.; Bartolomé, B.; Moreno-Arribas, M.V. Assessment of probiotic properties in lactic acid bacteria isolated from wine. Food Microbiol. 2014, 44, $220-225$. [CrossRef] [PubMed]

2. Nascimento, L.C.S.; Casarotti, S.N.; Todorov, S.D.; Penna, A.L.B. Probiotic potential and safety of enterococci strains. Annals Microbiol. 2019, 69, 241-252. [CrossRef]

3. Moreno, I.; Marasca, E.T.G.; de Sá, P.B.Z.R.; de Souza Moitinho, J.; Marquezini, M.G.; Alves, M.R.C.; Bromberg, R. Evaluation of probiotic potential of bacteriocinogenic lactic acid bacteria strains isolated from meat products. Probiotics Antimicrob. Proteins 2018, 10, 762-774. [CrossRef] [PubMed]

4. Milani, C.; Lugli, G.A.; Duranti, S.; Turroni, F.; Bottacini, F.; Mangifesta, M.; Sanchez, B.; Viappiani, A.; Mancabelli, L.; Taminiau, B. Genomic encyclopedia of type strains of the genus Bifidobacterium. Appl. Environ. Microbiol. 2014, 80, 6290-6302. [CrossRef]

5. Verso, L.L.; Lessard, M.; Talbot, G.; Fernandez, B.; Fliss, I. Isolation and selection of potential probiotic bacteria from the pig gastrointestinal tract. Probiotics Antimicrob. Proteins 2018, 10, 299-312. [CrossRef]

6. Curto, A.L.; Pitino, I.; Mandalari, G.; Dainty, J.R.; Faulks, R.M.; Wickham, M.S.J. Survival of probiotic lactobacilli in the upper gastrointestinal tract using an in vitro gastric model of digestion. Food Microbiol. 2011, 28, 1359-1366. [CrossRef]

7. Yu, Z.; Zhang, X.; Li, S.; Li, C.; Li, D.; Yang, Z. Evaluation of probiotic properties of Lactobacillus plantarum strains isolated from Chinese sauerkraut. World J. Microbiol. Biotechnol. 2013, 29, 489-498. [CrossRef]

8. Riaz, T.; Iqbal, M.W.; Saeed, M.; Yasmin, I.; Hassanin, H.A.; Mahmood, S.; Rehman, A. In vitro survival of Bifidobacterium bifidum microencapsulated in zein-coated alginate hydrogel microbeads. J. Microencap. 2019, 36, 192-203. [CrossRef]

9. Ayhan, D.K.; Temiz, A.; Sana, F.A.; Gümüşderelioğlu, M. Surface properties and exopolysaccharide production of surface-associated microorganisms isolated from a dairy plant. Ann. Microbiol. 2019, 69, 895-907. [CrossRef]

10. Ren, D.; Li, C.; Qin, Y.; Yin, R.; Du, S.; Ye, F.; Liu, C.; Liu, H.; Wang, M.; Li, Y.; et al. In vitro evaluation of the probiotic and functional potential of Lactobacillus strains isolated from fermented food and human intestine. Anaerobe 2014, 30, 1-10. [CrossRef]

11. Yateem, A.; Balba, M.; Al-Surrayai, T.; Al-Mutairi, B.; Al-Daher, R. Isolation of lactic acid bacteria with probiotic potential from camel milk. Inter. J. Dairy Sci. 2008, 3, 194-199. [CrossRef]

12. Ashmaig, A.; Hasan, A.; El Gaali, E. Identification of lactic acid bacteria isolated from traditional Sudanese fermented camels milk (Gariss). Afri. J. Microbiol. Res. 2009, 3, 451-457.

13. Amina, Z.; Noureddine, S.; Venkatesan, A.; Perumal, V.; Hichem, B.; Asma, Z.; Yamina, M.; Miloud, H.; Mebrouk, K. Characterization and potential probiotic attributes of Lactobacillus plantarum DU10 isolated from Algerian raw camel milk. Biotechnology 2014, 13, 282-288.

14. Carballo, J. Potential technological interest of indigenous lactic acid bacteria from Algerian camel milk. Ital. J. Food Sci. 2016, 28, 598-611.

15. Biratu, K.; Seifu, E. Chemical composition and microbiological quality of Dhanaan: Traditional fermented camel milk produced in eastern Ethiopia. Inter. Food Res. J. 2016, 23, 2223-2228.

16. Fguiri, I.; Ziadi, M.; Atigui, M.; Ayeb, N.; Arroum, S.; Assadi, M.; Khorchani, T. Isolation and characterisation of lactic acid bacteria strains from raw camel milk for potential use in the production of fermented Tunisian dairy products. Inter. J. Dairy Technol. 2016, 69, 103-113. [CrossRef]

17. Mahmoudi, I.; Moussa, O.B.; Khaldi, T.E.M.; Kebouchi, M.; Soligot, C.; Le Roux, Y.; Hassouna, M. Functional in vitro screening of Lactobacillus strains isolated from Tunisian camel raw milk toward their selection as probiotic. Small Rumin. Res. 2016, 137, 91-98. [CrossRef]

18. Soleymanzadeh, N.; Mirdamadi, S.; Kianirad, M. Antioxidant activity of camel and bovine milk fermented by lactic acid bacteria isolated from traditional fermented camel milk (Chal). Dairy Sci. Technol. 2016, 96, 443-457. [CrossRef]

19. Wang, Y.; Zhou, J.; Xia, X.; Zhao, Y.; Shao, W. Probiotic potential of Lactobacillus paracasei FM-LP-4 isolated from Xinjiang camel milk yoghurt. Inter. Dairy J. 2016, 62, 28-34. [CrossRef]

20. Abushelaibi, A.; Al-Mahadin, S.; El-Tarabily, K.; Shah, N.P.; Ayyash, M. Characterization of potential probiotic lactic acid bacteria isolated from camel milk. LWT-Food Sci. Technol. 2017, 79, 316-325. [CrossRef] 
21. Kuo, J.; Yang, Y.-T.; Lu, M.-C.; Wong, T.-Y.; Sung, P.-J.; Huang, Y.-S. Antimicrobial activity and diversity of bacteria associated with Taiwanese marine sponge Theonella swinhoei. Ann. Microbiol. 2019, 69, 253-265. [CrossRef]

22. Gao, Y.; Li, D. Screening of lactic acid bacteria with cholesterol-lowering and triglyceride-lowering activity in vitro and evaluation of probiotic function. Ann. Microbiol. 2018, 68, 537-545. [CrossRef]

23. Sybesma, W.; Kort, R.; Lee, Y.-K. Locally sourced probiotics, the next opportunity for developing countries? Trends Biotechnol. 2015, 33, 197-200. [CrossRef]

24. Yadav, R.; Puniya, A.K.; Shukla, P. Probiotic properties of Lactobacillus plantarum RYPR1 from an indigenous fermented beverage Raabadi. Front. Microbiol. 2016, 7, 1683. [CrossRef]

25. Yasmin, I.; Saeed, M.; Pasha, I.; Zia, M.A. Development of Whey Protein Concentrate-Pectin-Alginate Based Delivery System to Improve Survival of B. longum BL-05 in Simulated Gastrointestinal Conditions. Probiotics Antimicrob. Proteins 2019, 11, 413-426. [CrossRef] [PubMed]

26. Liu, C.F.; Tseng, K.C.; Chiang, S.S.; Lee, B.H.; Hsu, W.H.; Pan, T.M. Immunomodulatory and antioxidant potential of Lactobacillus exopolysaccharides. J. Sci. Food Agric. 2011, 91, 2284-2291. [CrossRef]

27. Nikolic, M.; López, P.; Strahinic, I.; Suárez, A.; Kojic, M.; Fernández-García, M.; Topisirovic, L.; Golic, N.; Ruas-Madiedo, P. Characterisation of the exopolysaccharide (EPS)-producing Lactobacillus paraplantarum BGCG11 and its non-EPS producing derivative strains as potential probiotics. Inter. J. Food Microbiol. 2012, 158, 155-162. [CrossRef]

28. Xu, H.; Jeong, H.; Lee, H.; Ahn, J. Assessment of cell surface properties and adhesion potential of selected probiotic strains. Lett. App. Microbiol. 2009, 49, 434-442. [CrossRef]

29. Kotzamanidis, C.; Kourelis, A.; Litopoulou-Tzanetaki, E.; Tzanetakis, N.; Yiangou, M. Evaluation of adhesion capacity, cell surface traits and immunomodulatory activity of presumptive probiotic Lactobacillus strains. Inter. J. Food Microbiol. 2010, 140, 154-163. [CrossRef]

30. Chen, F.A.; Wu, A.B.; Shieh, P.; Kuo, D.H.; Hsieh, C.Y. Evaluation of the antioxidant activity of Ruellia tuberosa. Food Chem. 2006, 94, 14-18. [CrossRef]

31. Oberg, T.; Steele, J.; Ingham, S.; Smeianov, V.; Briczinski, E.; Abdalla, A.; Broadbent, J.R. Intrinsic and inducible resistance to hydrogen peroxide in Bifidobacterium species. J. Indus. Microbiol. Biotechnol. 2011, 38, 1947-1953. [CrossRef] [PubMed]

32. Wu, Y.Y.; Liu, F.J.; Li, L.H.; Yang, X.Q.; Deng, J.C.; Chen, S.J. Isolation and identification of nitrite-degrading lactic acid bacteria from salted fish. Adv. Mater. Res. 2012, 393, 828-834. [CrossRef]

33. Yan, P.M.; Xue, W.T.; Tan, S.S.; Zhang, H.; Chang, X.H. Effect of inoculating lactic acid bacteria starter cultures on the nitrite concentration of fermenting Chinese paocai. Food Control 2008, 19, 50-55. [CrossRef]

34. Rudel, L.L.; Morris, M. Determination of cholesterol using o-phthalaldehyde. J. Lipid Res. 1973, 14, 364-366. [PubMed]

35. Liong, M.; Shah, N. Bile salt deconjugation ability, bile salt hydrolase activity and cholesterol co-precipitation ability of lactobacilli strains. Int. Dairy J. 2005, 15, 391-398. [CrossRef]

36. Vijayakumar, M.; Ilavenil, S.; Kim, D.H.; Arasu, M.V.; Priya, K.; Choi, K.C. In-vitro assessment of the probiotic potential of Lactobacillus plantarum KCC-24 isolated from Italian rye-grass (Lolium multiflorum) forage. Anaerobe 2015, 32, 90-97. [CrossRef]

37. Mangia, N.P.; Saliba, L.; Deiana, P. Functional and safety characterization of autochthonous Lactobacillus paracasei FS103 isolated from sheep cheese and its survival in sheep and cow fermented milks during cold storage. Ann. Microbiol. 2019, 69, 161-170. [CrossRef]

38. Mohanty, D.; Panda, S.; Kumar, S.; Ray, P. In vitro evaluation of adherence and anti-infective property of probiotic Lactobacillus plantarum DM 69 against Salmonella enterica. Microbial. Pathog. 2019, 126, $212-217$. [CrossRef]

39. Martinez, I.; Stegen, J.C.; Maldonado-Gomez, M.X.; Eren, A.M.; Siba, P.M.; Greenhill, A.R.; Walter, J. The gut microbiota of rural papua new guineans: Composition, diversity patterns, and ecological processes. Cell Rep. 2015, 11, 527-538. [CrossRef]

40. Choudhary, J.; Dubey, R.; Sengar, G.; Dheeman, S. Evaluation of probiotic potential and safety assessment of Lactobacillus pentosus MMP4 isolated from mare's lactation. Probiotics Antimicrob. Proteins 2019, 11, 403-412. [CrossRef]

41. Khan, W.A.; Butt, M.S.; Pasha, I.; Jamil, A. Microencapsulation of vitamin D in protein matrices: In vitro release and storage stability. J. Food Meas. Charact. 2020, 1-11. [CrossRef] 
42. Izquierdo, E.; Medina, M.; Ennahar, S.; Marchioni, E.; Sanz, Y. Resistance to simulated gastrointestinal conditions and adhesion to mucus as probiotic criteria for Bifidobacterium longum strains. Curr. Microbiol. 2008, 56, 613-618. [CrossRef] [PubMed]

43. Jia, L.; Shigwedha, N.; Mwandemele, O.D. Use of Dacid-, Dbile-, zacid-, and zbile-Values in Evaluating Bifidobacteria with Regard to Stomach $\mathrm{pH}$ and Bile Salt Sensitivity. J. Food Sci. 2010, 75. [CrossRef]

44. Casarotti, S.N.; Penna, A.L.B. Acidification profile, probiotic in vitro gastrointestinal tolerance and viability in fermented milk with fruit flours. Inter. Dairy J. 2015, 41, 1-6. [CrossRef]

45. Larsen, N.; Cahú, T.B.; Saad, S.M.I.; Blennow, A.; Jespersen, L. The effect of pectins on survival of probiotic Lactobacillus spp. in gastrointestinal juices is related to their structure and physical properties. Food Microbiol. 2018, 74, 11-20. [CrossRef]

46. Sanchez, B.; Champomier-Verges, M.C.; Collado Mdel, C.; Anglade, P.; Baraige, F.; Sanz, Y.; de los Reyes-Gavilan, C.G.; Margolles, A.; Zagorec, M. Low-pH adaptation and the acid tolerance response of Bifidobacterium longum biotype longum. Appl. Environ. Microbiol. 2007, 73, 6450-6459. [CrossRef] [PubMed]

47. Haros, M.; Carlsson, N.G.; Almgren, A.; Larsson-Alminger, M.; Sandberg, A.S.; Andlid, T. Phytate degradation by human gut isolated Bifidobacterium pseudocatenulatum ATCC27919 and its probiotic potential. Inter. J. Food Microbiol. 2009, 135, 7-14. [CrossRef] [PubMed]

48. Haghshenas, B.; Abdullah, N.; Nami, Y.; Radiah, D.; Rosli, R.; Khosroushahi, A.Y. Different effects of two newly-isolated probiotic Lactobacillus plantarum $15 \mathrm{HN}$ and Lactococcus lactis subsp. Lactis 44Lac strains from traditional dairy products on cancer cell lines. Anaerobe 2014, 30, 51-59. [CrossRef]

49. Bengoa, A.A.; Llamas, M.G.; Iraporda, C.; Dueñas, M.T.; Abraham, A.G.; Garrote, G.L. Impact of growth temperature on exopolysaccharide production and probiotic properties of Lactobacillus paracasei strains isolated from kefir grains. Food Microbiol. 2018, 69, 212-218. [CrossRef]

50. Prasanna, P.; Grandison, A.S.; Charalampopoulos, D. Screening human intestinal Bifidobacterium strains for growth, acidification, EPS production and viscosity potential in low-fat milk. Inter. Dairy J. 2012, 23, 36-44. [CrossRef]

51. Alp, G.; Aslim, B. Relationship between the resistance to bile salts and low pH with exopolysaccharide (EPS) production of Bifidobacterium spp. isolated from infants feces and breast milk. Anaerobe 2010, 16, 101-105. [CrossRef] [PubMed]

52. Rahman, M.M.; Kim, W.-S.; Kumura, H.; Shimazaki, K.-i. Autoaggregation and surface hydrophobicity of bifidobacteria. World J. Microbiol. Biotechnol. 2008, 24, 1593-1598. [CrossRef]

53. Russell, D.A.; Ross, R.P.; Fitzgerald, G.F.; Stanton, C. Metabolic activities and probiotic potential of bifidobacteria. Inter. J. Food Microbiol. 2011, 149, 88-105. [CrossRef] [PubMed]

54. Shen, Q.; Shang, N.; Li, P. In vitro and in vivo antioxidant activity of Bifidobacterium animalis 01 isolated from centenarians. Cur. Microbiol. 2011, 62, 1097-1103. [CrossRef]

55. Wang, Y.-C.; Yu, R.-C.; Chou, C.-C. Antioxidative activities of soymilk fermented with lactic acid bacteria and bifidobacteria. Food Microbiol. 2006, 23, 128-135. [CrossRef]

56. Soubra, L.; Sarkis, D.; Hilan, C.; Verger, P. Dietary exposure of children and teenagers to benzoates, sulphites, butylhydroxyanisol (BHA) and butylhydroxytoluen (BHT) in Beirut (Lebanon). Regul. Toxicol. Pharm. 2007, 47, 68-77. [CrossRef]

57. Collado, M.; Gonzalez, A.; Gonzalez, R.; Hernandez, M.; Ferrus, M.; Sanz, Y. Antimicrobial peptides are among the antagonistic metabolites produced by Bifidobacterium against Helicobacter pylori. Inter. J. Anti. Agents 2005, 25, 385-391. [CrossRef]

58. El-Gawad, I.A.A.; El-Sayed, E.; Hafez, S.; El-Zeini, H.; Saleh, F. The hypocholesterolaemic effect of milk yoghurt and soy-yoghurt containing bifidobacteria in rats fed on a cholesterol-enriched diet. Int. Dairy J. 2005, 15, 37-44. [CrossRef]

59. Xiao, J.; Kondo, S.; Takahashi, N.; Miyaji, K.; Oshida, K.; Hiramatsu, A.; Iwatsuki, K.; Kokubo, S.; Hosono, A. Effects of milk products fermented by Bifidobacterium longum on blood lipids in rats and healthy adult male volunteers. J. Dairy Sci. 2003, 86, 2452-2461. [CrossRef]

60. Zhou, J.; Pillidge, C.; Gopal, P.; Gill, H. Antibiotic susceptibility profiles of new probiotic Lactobacillus and Bifidobacterium strains. Inter. J. Food Microbiol. 2005, 98, 211-217. [CrossRef]

61. Temmerman, R.; Pot, B.; Huys, G.; Swings, J. Identification and antibiotic susceptibility of bacterial isolates from probiotic products. Int. J. Food Microbiol. 2003, 81, 1-10. [CrossRef] 
62. Oh, Y.J.; Jung, D.S. Evaluation of probiotic properties of Lactobacillus and Pediococcus strains isolated from Omegisool, a traditionally fermented millet alcoholic beverage in Korea. LWT-Food Sci. Technol. 2015, 63, 437-444. [CrossRef]

63. Wang, J.; Yang, K.; Liu, M.; Zhang, J.; Wei, X.; Fan, M. Screening for potential probiotic from spontaneously fermented non-dairy foods based on in vitro probiotic and safety properties. Ann. Microbiol. 2018, 68, 803-813. [CrossRef]

64. Bujnakova, D.; Strakova, E. Safety, probiotic and technological properties of Lactobacilli isolated from unpasteurised ovine and caprine cheeses. Ann. Microbiol. 2017, 67, 813-826. [CrossRef]

65. Nami, Y.; Haghshenas, B.; Bakhshayesh, R.V.; Jalaly, H.M.; Lotfi, H.; Eslami, S.; Hejazi, M.A. Novel autochthonous lactobacilli with probiotic aptitudes as a main starter culture for probiotic fermented milk. LWT-Food Sci. Technol. 2018, 98, 85-93. [CrossRef]

66. Tarrah, A.; da Silva Duarte, V.; de Castilhos, J.; Pakroo, S.; Junior, W.J.F.L.; Luchese, R.H.; Guerra, A.F.; Rossi, R.C.; Ziegler, D.R.; Corich, V. Probiotic potential and biofilm inhibitory activity of Lactobacillus casei group strains isolated from infant feces. J. Funct. Foods. 2019, 54, 489-497. [CrossRef]

67. Chiu, Y.-H.; Lu, Y.-C.; Ou, C.-C.; Lin, S.-L.; Tsai, C.-C.; Huang, C.-T.; Lin, M.-Y. Lactobacillus plantarum MYL26 induces endotoxin tolerance phenotype in Caco-2 cells. BMC Microbiol. 2013, 13, 190. [CrossRef]

68. Awaisheh, S.; Obeidat, M.; Al-Tamimi, H.; Assaf, A.; EL-Qudah, J.; Rahahleh, R. In vitro cytotoxic activity of probiotic bacterial cell extracts against Caco-2 and HRT-18 colorectal cancer cells. Milk Sci. Inter.-Milchwiss. 2016, 69, 33-37.

69. Er, S.; KOPARAL, A.T.; Kivanc, M. Cytotoxic effects of various lactic acid bacteria on Caco-2 cells. Turk. J. Biol. 2015, 39, 23-30. [CrossRef]

70. Bhat, M.I.; Singh, V.K.; Sharma, D.; Kapila, S.; Kapila, R. Adherence capability and safety assessment of an indigenous probiotic strain Lactobacillus rhamnosus MTCC-5897. Microbial Pathog. 2019, 130, 120-130. [CrossRef]

71. Joghataei, M.; Shahidi, F.; Pouladfar, G.; Mortazavi, S.A.; Ghaderi, A. Probiotic potential comparison of Lactobacillus strains isolated from Iranian traditional food products and human feces with standard probiotic strains. J. Sci. Food Agric. 2019. [CrossRef] [PubMed]

72. Lee, N.-K.; Hong, J.-Y.; Yi, S.-H.; Hong, S.-P.; Lee, J.-E.; Paik, H.-D. Bioactive compounds of probiotic Saccharomyces cerevisiae strains isolated from cucumber jangajji. J. Funct. Foods 2019, 58, 324-329. [CrossRef]

73. Ozkan, A.D.; Han, D.; Umu, O.C.; Angun, P.; Senturk, B.; Yasa, O.; Tekinay, T. Screening and selection of novel animal probiotics isolated from bovine chyme. Ann. Microbiol. 2013, 63, 1291-1300. [CrossRef]

74. Le Leu, R.K.; Hu, Y.; Brown, I.L.; Woodman, R.J.; Young, G.P. Synbiotic intervention of Bifidobacterium lactis and resistant starch protects against colorectal cancer development in rats. Carcinogenesis 2009, 31, $246-251$. [CrossRef] [PubMed]

(C) 2020 by the authors. Licensee MDPI, Basel, Switzerland. This article is an open access article distributed under the terms and conditions of the Creative Commons Attribution (CC BY) license (http://creativecommons.org/licenses/by/4.0/). 